\title{
35. GEOCHEMICAL HISTORY OF POST-JURASSIC SEDIMENTATION IN THE CENTRAL NORTHWESTERN PACIFIC, WESTERN MID-PACIFIC MOUNTAINS, DEEP SEA DRILLING PROJECT SITE 4631
}

\author{
I. M. Varentsov, P. P. Timofeev, and M. A. Rateev, Geological Institute of the \\ U.S.S.R. Academy of Sciences, Moscow, U.S.S.R.
}

\begin{abstract}
Distribution of the main components and heavy metals, the mode of their occurrence, and data on mineralogy and lithology of post-Jurassic sediments in the Mid-Pacific Mountains allow us to outline three main stages in the geochemical history of sedimentation:

1) Early Cretaceous stage (late Barremian-late Albian). During this time, the accumulation of relatively shallowwater carbonate sediments with considerable basaltic volcanic material took place. Relatively great amounts of heavy metals are present in the form of altered volcaniclastic material and, to a lesser degree, as hydrothermal exhalates. The volcanic activity reached its maximum in the middle part of the early Aptian with accumulation of tuffaceous carbonate oozes with a high content of sapropelic material, in the environments of a stagnant basin. High rates of accumulation of the main components and heavy metals are close to the values of the proto-oceanic stage of development.

2) Late Cretaceous stage (late Albian-Maastrichtian). This stage is characterized by intermediate conditions of sedimentation and geochemical parameters. The early Maastrichtian was distinguished by high accumulation rates of carbonates and heavy metals, owing to the fact that the western Mid-Pacific Mountains were located in the equatorial zone, with high biological productivity, in the course of northward movement of the Pacific Plate.

3) Cenozoic stage (Eocene-Holocene). This stage is characterized by abundant hiatuses and relatively stable accumulation of foraminifer-nannofossil oozes, with the environments similar to that of the Recent.
\end{abstract}

\section{INTRODUCTION}

The relative completeness of the post-Jurassic sediment sequence in the Mid-Pacific Mountains allows us to consider it as a key section for studying the evolution of Mesozoic and Cenozoic sedimentation in the northwest central Pacific. That was the main objective in selection of Site 463, DSDP Leg 62 (Site 463 report, this volume).

Earlier investigations covered the main features of Mesozoic and Cenozoic sedimentation in this region (Fisher, Heezen, et al., 1971; Hamilton, 1956; Heezen, Hoskins et al., 1973; Lancelot, 1978; Lancelot and Larson, 1975; Van Andel et al., 1975, 1976; Winterer, 1976; Winterer, Ewing, et al., 1973; Larson, Moberly, et al., 1975).

These works deal mainly with problems of relationships between sedimentation and features of tectonic development, volcanism, paleoceanography, and other factors.

The objective of this work is the study of geochemical aspects of post-Jurassic sedimentation in the western Mid-Pacific Mountains. It is supposed that essential processes of sedimentation and post-sedimentary transformations were recorded in the chemical and mineral composition of the sediments. Among the primary tasks of this study are (1) determination of the geochemical nature of Mesozoic-Cenozoic sedimentation evolution in the Pacific regions concerned, (2) study of the geochemistry of the change of sedimentation conditions at

\footnotetext{
1 Initial Reports of the Deep Sea Drilling Project, Volume 62.
}

the Mesozoic/Cenozoic boundary and at the major geochronologic subdivisions; (3) determination of the geochemical nature of the main sedimentation stages, postsedimentary changes, and the characteristics of the controlling factors.

\section{MATERIALS AND RETHODS}

The data on chemical and mineral composition and lithologic features of deposits penetrated by Hole 463 and obtained by the Geological Institute of the U.S.S.R. Academy of Sciences are the basis of this work. Information on lithologic-mineralogical studies is given in other chapters of this volume. All the chemically analyzed samples were studied as thin sections under a microscope for general classification, and by X-ray structural analysis, using slides prepared either from the natural sediment or its size fractions. Determination of chemical components of the sediment was made in the analytical laboratory of the Geological Institute of the U.S.S.R. Academy of Sciences, the main components by methods of bulk wet chemical analysis, heavy metals by spectral techniques, in comparison with international reference standards (Zolotarev and Choporov, 1978).

The chemical analyses were recalculated on a clastic-free, silicafree, and carbonate-free basis (here called "mineral-free"), to exclude the diluting influence of (1) terrigenous matter, (2) siliceous matter, (3) carbonates, (4) organic matter, and (5) salts of sea water (sulphates, chlorides), and to adjust to a geochemically comparable basis (Varentsov and Blazhchishin, 1976; Varentsov, 1978).

Analytical data were processed by computer (EC-1022) in the Laboratory of Mathematical Methods, Geological Institute of the U.S.S.R. Academy of Sciences (D. A. Kazimirov, P. K. Ryabushkin), using factor analysis (R- and Q-mode; Davis, 1973; Harman, 1967).

The structural position of Site 463 is reflected in the chemical composition of Mesozoic-Cenozoic deposits. Its characteristics are documented in the mineral and chemical composition of sediments, which resulted in the separation of the distinct geochemical clusters or paragenetic assemblages of the components. Such clusters (groups) are revealed after processing the chemical-analysis data by factor analysis; the interpretation of composition of the clusters allows us to consider the geochemical nature of such assemblages either as com- 
pounds and phases, or as specific forms of occurrence of the established groups of components.

Determination of assemblages was made by grouping of components with factor loadings greater than or equal to an absolute value of 0.30 . Two assemblages of different signs and compositions can be identified in each factor.

Each chemical component is characterized by a value of factor loading (in brackets) which is closely associated with the interrelationships between the components in a specific assemblage. The number of the assemblage corresponds to the number of the factor. It is presumed that characteristic loadings on other factors for each given assemblage are close to 0 . This results in revealing components of the assemblages and their distribution throughout the section. The data were transformed by rotation methods to obtain more-distinct values of factor loadings (Varimax by Kaiser; see Davis, 1973).

\section{PARAGENETIC ASSEMBLAGES OF COMPONENTS}

The data on bulk chemical analysis (wt.\%, recalculated to air-dry weight) and results of recalculation of the chemical analyses to a mineral-free basis were processed to establish qualitative relationships between components of paragenetic associations. The obtained data allow us to determine geochemical groups of components, corresponding to the real composition of the sediments under study. However, the high predominance of carbonate and silicate components and their distinct diluting effect conceal specific authigenic products of hydrothermal, volcanic, and post-sedimentary transformations. Different methods of geochemical recalculations were applied to compensate for such diluting effects (Boström, 1973). The specific methods applied in this study were shown in a number of earlier works (Varentsov and Blazhchishin, 1976; Varentsov, 1978). It should be emphasized that the basis for interpretation of the paragenetic assemblages of chemical components are the data on mineral composition and the implied processes of their formation.

CHEMICAL ANALYSES (Tables 1-3; Fig. 1)

Assemblage IA (+): $\mathrm{Al}_{2} \mathrm{O}_{3}(0.29)-\mathrm{Na}_{2} \mathrm{O}(0.53)-\mathrm{K}_{2} \mathrm{O}$ (0.57)-C (0.34)-Fe(0.45)-Cr(0.93)-Ni(0.85)-V(0.90)-Cu (0.82)-Co(0.84)-Ga(0.67)-Ge(0.57). The set of components and the data on mineral composition of sediments distinctly indicate that this group is best represented (Fig. 1) by illite, mixed-layer montmorillonite-illite with a zeolite admixture, and heavy metals. The organic matter can be present in interlayer spaces of the mixed-layer clays, which resulted from alteration of volcaniclastic material, distinctly observed under the microscope. The mixed-layered clays are particularly typical of the tuffaceous limestones with a relatively increased content of organic matter (Sample 70-5, 99-100 cm, lower Aptian) and the multicolored (gray in this case) limestones in the upper Aptian, with a considerable admixture of volcaniclastic material. This assemblage is less distinctly developed in lower Maastrichtian sediments (Fig. 1).

Assemblage IB (-): $\mathrm{CaO}(-0.42)-\mathrm{CO}_{2}(-0.38)$. Distribution of calcium carbonate is shown in Figure 1. The absence of some other components in this group and their preferential occurrences in upper Barremian-upper Aptian rocks composed of recrystallized limestones shows that the assemblage concerned is represented by almost pure calcite as a product of late diagenetic recrystallization. It should be emphasized that distribution of such calcite is confined to Units II to IV (Fig. 1), with density values exceeding $1.89 \mathrm{~g} / \mathrm{cm}^{3}$ (Site 463 report, this volume).

Assemblage IIA (+): $\mathrm{CaO}(0.64)-\mathrm{Na}_{2} \mathrm{O}(0.61)-\mathrm{CO}_{2}$ (0.61). The group of components concerned is represented by calcium carbonate composing nannofossilforaminifer and foraminifer-nannofossil micritic oozes and chalk of corresponding composition. A characteristic component of this group is $\mathrm{Na}_{2} \mathrm{O}$, which is found in diagenetically weakly altered carbonate sediments. It should be noted that the assemblage concerned is rather distinctly manifested within Sub-units IA and IB, where density ranges from 1.61 to $1.89 \mathrm{~g} / \mathrm{cm}^{3}$ (Site 463 report, this volume). The assemblage is almost absent in the underlying sediments, with a density of 1.93 $\mathrm{g} / \mathrm{cm}^{3}$ and over (Fig. 1). It is known that the process of diagenetic transformation during recrystallization of biogenic carbonate is accompanied by liberation of $\mathrm{Na}$ and its transition into pore solutions.

Assemblage IIB (-): $\mathrm{SiO}_{2}(-89)-\mathrm{Al}_{2} \mathrm{O}_{3}(-0.71)-$ $\mathrm{MgO}(-0.52)-\mathrm{K}_{2} \mathrm{O}(-0.63)-\mathrm{Fe}(-0.63)$. This assemblage is represented by the components composing a $\mathrm{K}$-bearing $\mathrm{Fe}, \mathrm{Mg}$-smectite, mixed-layer illite-montmorillonite, and illite proper; these occur in variable amounts, from one clay predominating to various admixtures. Distribution of this group in the section is restricted to upper Barremian-upper Turonian sediments. The most distinct manifestations of this assemblage are found in deposits enriched by altered volcaniclastic material of basic and average composition: upper Barremian limestones; lower Aptian olive-green limestones; tuffaceous limestones with organic remains; and multicolored, predominantly red upper Aptian-lower Albian limestones.

Assemblage IIIA (+): $\mathrm{CaO}(0.48)-\mathrm{CO}_{2}(0.56)-\mathrm{Al}_{2} \mathrm{O}_{3}$ (0.14)- $\mathbf{G a}(0.14)$. This assemblage is represented by calcium carbonate; however, its mineralogical features are not sufficiently clear. Some peculiarities (Fig. 1) deserve attention: (1) In the lower part of the section (upper Barremian-middle Turonian; Sample 85-1, 100-101 cm up to $34-1,32-34 \mathrm{~cm}$ ), the assemblage is accompanied, as a rule, by the components of assemblage IIB (-), represented by K-bearing smectite, mixed-layer smectite-illite, and illite. (2) In the lower Santonian-Pleistocene interval, IIIA $(+)$ occupies the same levels as assemblage IA $(+)$ (illite and mixed-layer illite-montmorillonite).

The earlier mentioned assemblages of calcium carbonates are, on the one hand, initial biomorphic carbonates [IIA $(+)$ ], not subjected to considerable postsedimentation alterations, and on the other hand calcium carbonates [IB $(-)$ ], the result of epigenetic recrystallization; the IIIA (+) assemblage occupies an intermediate position. The given set of components can be considered a relict phase, formed during recrystallization and dissolution of the biomorphic carbonate; it is somewhat enriched in alumina.

Assemblage IIIB (-): $\mathrm{C}(-0.69)-\mathrm{Mn}(-0.36)-\mathrm{Ni}$ $(-0.44)-\mathrm{Co}(-0.46)-\mathrm{Pb}(-0.57)-\mathrm{Mo}(-0.86)$. The set of components of the assemblage concerned definitely 
Table 1. Chemical composition of Mesozoic-Cenozoic deposits, northwest Pacific, western Mid-Pacific Mountains, DSDP Site 463.

\begin{tabular}{|c|c|c|c|c|c|c|c|c|c|c|c|c|c|c|c|c|c|c|c|c|c|c|c|}
\hline \multirow{2}{*}{$\begin{array}{c}\text { Sample } \\
\text { (interval in } \mathrm{cm} \text { ) }\end{array}$} & \multicolumn{14}{|c|}{ Components (wt.\%, air-dry basis) } & $\mathrm{Cr}$ & $\mathrm{Ni}$ & v & $\mathrm{Cu}$ & Co & $\mathrm{Pb}$ & Sa & $\mathrm{Ge}$ & 10 \\
\hline & $\mathrm{SiO}_{2}$ & $\mathrm{Al}_{2} \mathrm{O}_{3}$ & $\mathrm{Fe}_{2} \mathrm{O}_{3}$ & $\mathrm{CaO}$ & $\mathrm{MgO}$ & $\mathrm{MnO}$ & $\mathrm{Na}_{2} \mathrm{O}$ & $\mathrm{K}_{2} \mathrm{O}$ & $\mathrm{CO}_{2}$ & $\mathrm{C}_{\text {org }}$ & $\mathrm{P}_{2} \mathrm{O}_{5}$ & $\mathrm{Fe}$ & $\mathrm{Mn}$ & $\mathbf{P}$ & \multicolumn{9}{|c|}{ (wt. $\left.\% \times 10^{4}\right)$} \\
\hline $3-1-1,70-72$ & 9.19 & 2.93 & 1.48 & 45.15 & 0.58 & 0.08 & 1.43 & 0.75 & 35.20 & nil & 0.11 & 1.04 & 0.06 & 0.05 & 11 & 12 & 5 & 0 & 10 & 10 & 5 & 1 & 1.5 \\
\hline $3-2,48-50$ & 2.16 & 0.70 & 0.69 & 52.47 & 0.16 & 0.05 & 1.10 & 0.31 & 41.49 & nil & 0.11 & 0.48 & 0.04 & 0.05 & $<10$ & $<10$ & $<15$ & & & & & 1 & 1.5 \\
\hline $4-3,20-22$ & 2.46 & 1.02 & 0.56 & 51.02 & 0.42 & 0.07 & 1.25 & 0.33 & & nit & 017 & 0.39 & 0.05 & 0.07 & $<10$ & $<10$ & $<15$ & $<20$ & $<10$ & $<10$ & $<5$ & $<1$ & $<1.5$ \\
\hline $5-1,63-65$ & 0.22 & 0.03 & 0.35 & & nil & & 0.9 & 0.20 & & nil & & & & & & $<10$ & & & & $<10$ & $<5$ & $<1$ & $<1.5$ \\
\hline $6-3,59-61$ & 0.38 & 0.14 & 0.30 & 54.73 & 0.24 & 0.04 & 0.76 & 0.20 & 42.35 & nil & 0.07 & 0.21 & 0.03 & 0.03 & $<10$ & $<10$ & $<15$ & $<20$ & $<10$ & $<10$ & $<5$ & $<1$ & $<1.5$ \\
\hline $7-1,61-63$ & 0.32 & nil & 0.17 & 54.97 & & & & & & nil & & & 0.09 & & $<10$ & $<10$ & $<15$ & $<20$ & $<10$ & $<10$ & $<5$ & $<1$ & $<1.5$ \\
\hline $8-2,54-56$ & 91.10 & 1.05 & 1.62 & 2.70 & 0.02 & 0.04 & 0.23 & 0.25 & 1.20 & nil & 0.05 & 1.13 & 0.03 & 0.02 & 11 & 15 & $<15$ & 29 & $<10$ & $<10$ & $<5$ & $<1$ & 9.5 \\
\hline $8-3,34-36$ & 1.03 & 0.28 & 0.26 & 54.04 & 0.33 & 0.01 & 1.08 & 0.20 & 42.10 & nil & 0.07 & 0.18 & 0.01 & 0.03 & $<10$ & $<10$ & $<15$ & $<20$ & $<10$ & $<10$ & $<5$ & $<1$ & $<1.5$ \\
\hline $9-1,30-32$ & 6.84 & 0.68 & 0.24 & 50.00 & 0.59 & 0.01 & 1.01 & 0.36 & 38.55 & $n$ & 0. & 0.17 & 0.01 & 0.03 & $<10$ & $<10$ & $<15$ & $<20$ & $<10$ & $<10$ & $=5$ & $<1$ & $<1.5$ \\
\hline $10-1,78-80$ & 5.36 & 0.81 & 0.52 & & 0.09 & 0.01 & 0.85 & 0.41 & 39.00 & ni & 0. & 0.36 & 0.01 & 0.02 & $<10$ & $<10$ & $<15$ & $<20$ & $<10$ & $<10$ & $<5$ & $<1$ & $<1.5$ \\
\hline $11-1,72-74$ & 11.9 & 0.39 & 0.87 & 46.71 & nil & 0.01 & 1.45 & 0.31 & 36.50 & ni & 0 & 0.61 & 0.01 & 0. & $<10$ & $<10$ & $<15$ & $<20$ & $<10$ & $<10$ & $<5$ & $<1$ & 1.6 \\
\hline $12-1,30-32$ & 1.19 & nil & 0.21 & 52.29 & 0.83 & 0.21 & 1.06 & 0.23 & 40.60 & nil & & 0.15 & 0.16 & 0.02 & $<10$ & $<10$ & $<15$ & $<20$ & $<10$ & $<10$ & $<5$ & $<1$ & $<1.5$ \\
\hline $13-1,72-74$ & .60 & 0.25 & 0.26 & & 0.08 & 0.01 & 1.45 & 0.25 & 41. & II & & 0.18 & 0.01 & 0. & $<1$ & $<10$ & & $<20$ & & $<10$ & $<5$ & $<1$ & $<1.5$ \\
\hline $14-1,84-86$ & 0.62 & 0.17 & 0.17 & 53.88 & 0.16 & 0.01 & 1.64 & 0.25 & 42.05 & nil & 0.0 & 0.12 & 0.01 & 0.02 & $<10$ & $<10$ & $<15$ & $<20$ & $<10$ & $<10$ & $<5$ & $<1$ & $<1.5$ \\
\hline $15-2,70-72$ & 11.74 & 0.47 & 0.10 & 47.85 & 0.42 & tit & 0. & 0.25 & & nil & & 0.07 & in & 0. & $<10$ & $<10$ & $<15$ & $<20$ & $<10$ & $<10$ & $<5$ & $<1$ & $<1.5$ \\
\hline $16-2,8$ & 1.48 & 0.25 & 0.31 & 54.07 & nil & 0.01 & 1.27 & 0.31 & 41.75 & nil & 0.05 & 0.22 & 0.01 & 0.02 & $<10$ & $<10$ & $<15$ & $<20$ & $<10$ & $<10$ & $<5$ & $<1$ & $<1.5$ \\
\hline $17-1,86-88$ & 1.09 & & 0.35 & 84 & nil & 0.01 & 45 & 0.31 & 41.65 & nil & 00 & 0.24 & 0.01 & 0.0 & $<10$ & $<10$ & $<15$ & $<20$ & $<10$ & $<10$ & $<5$ & $<1$ & $<1.5$ \\
\hline $19-1,7$ & 18.24 & 0.49 & 0.30 & 44.49 & 0.34 & 0.01 & 0.75 & 0.20 & 33 & & & 0.21 & 0.01 & 0. & $<1$ & $<10$ & 3 & $<20$ & $<10$ & $<10$ & 5 & $<1$ & $<1.5$ \\
\hline $20-1,70-72$ & 1.29 & 0.20 & 0.43 & 5 & & & 1.3 & 0.3 & & & & 0.30 & 0.01 & & $<1$ & $<10$ & $<15$ & $<20$ & $<10$ & 10 & 5 & $<1$ & $<1.5$ \\
\hline $21-1,70-72$ & 0.76 & & & & $\mathrm{n}$ & 0.01 & 1. & 0.20 & & & & & 0. & & $<$ & $<$ & & 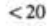 & $<$ & $<10$ & $<0$ & $<1$ & $=1.5$ \\
\hline $22-2,121-123$ & 0.95 & 0.12 & 52 & 5459 & 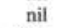 & 0.01 & 1.27 & 0.2 & & & & & 0.01 & 0. & $<1$ & $<1$ & $<$ & $<20$ & $<$ & $<10$ & $<5$ & $<1$ & $<1.5$ \\
\hline $24-1,93-95$ & 12.59 & nil & 63 & & 0.41 & nil & & 0.2 & & & & 0.44 & $\mathrm{~min}$ & & $<1$ & $<1$ & $<$ & $<20$ & $<$ & $<10$ & $<5$ & $<1$ & $<1.5$ \\
\hline $25-1,23-25$ & 2.46 & 0.37 & 52 & 33 & nil & 0.02 & 1.27 & 0.3 & 41. & n & & 0.36 & 0.02 & 0. & $<$ & $<1$ & $<$ & $<20$ & $<$ & $<10$ & 5 & $<1$ & $<1.5$ \\
\hline $26-1,118-12$ & 0.60 & nil & 0.50 & 12 & 0.49 & 0.0 & & 0. & 41. & nil & & 0. & 0. & . & $<$ & $<$ & $<$ & $<20$ & $<$ & 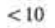 & 3 & 61 & $<1.5$ \\
\hline $27-1,118-120$ & 1.93 & nil & 0.88 & 52.73 & 0.17 & 0.04 & 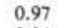 & 0.3 & 39.75 & 0.03 & 0.0 & 0. & 0.6 & 0. & $<1$ & $<1$ & $<1$ & $<20$ & $<$ & & $<5$ & 1 & $<1.5$ \\
\hline $30-1,100-102$ & 2.59 & 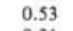 & & 5266 & 0.40 & 0.0 & 0. & 0.3 & 40.15 & il & & 0. & 0. & & & $<1$ & $<1$ & 0 & & & & & $<1.5$ \\
\hline $33-1,61-63$ & 3.45 & . & 96 & .38 & nil & 0.05 & 1. & 0.36 & 41. & & & 0.6 & 0.04 & 0. & $<1$ & $<1$ & $<1<+1$ & $<20$ & $<1$ & $<10$ & $<5$ & $<1$ & $<1.5$ \\
\hline $34-1,32-34$ & 9.55 & & & & 05 & & & 0.4 & & & & & & & & & & & & & & 1 & $<1 s$ \\
\hline $38-1,40-41$ & 3.02 & & & 43 & & 0. & & 0.2 & 40 & & & 0. & 0. & & $<1$ & $<1$ & $<$ & $<2$ & $<$ & $<10$ & $<5$ & $<1$ & $<1.5$ \\
\hline $43-1,50-51$ & 0.28 & nil & 6 & & & & & & & & & & & & & & & $<$ & $<$ & & $<5$ & $<1$ & $<1.5$ \\
\hline $48-1,64-66$ & 37.52 & 1.01 & 87 & .08 & 0.16 & 0. & 0.9 & 0.3 & 20. & $\pi$ & & 0.61 & 0. & 0. & $<$ & $<1$ & $<$ & $<$ & $<1$ & $<10$ & $<5$ & $<1$ & $<1.5$ \\
\hline $50-1,64-65$ & 94 & 1.05 & & 1 & 0.14 & & & 0. & & 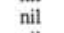 & & 0.3 & 0. & 0. & $<$ & $<1$ & $<$ & $<$ & $<$ & $<10$ & $<5$ & $<1$ & $<1.5$ \\
\hline $55-1,4-5$ & 27.96 & 0.27 & .12 & 36.32 & 0 & 0.0 & & 0 & 28. & $\mathrm{n}$ & & 1.48 & 0. & 0. & $<1$ & $<1$ & $<$ & $<$ & $<1$ & $<10$ & $<5$ & $<1$ & $<1.5$ \\
\hline $56-1$, & 39 & 0.07 & 49 & 38 & 0 & 0.0 & 0.5 & 0. & 38.8 & & & 0.34 & 0. & 0. & $<1$ & $<1$ & $<$ & $<$ & $<$ & $<10$ & $<5$ & $<1$ & $<1.5$ \\
\hline $57-1,2$ & 12.00 & 1.13 & & 16 & 1.2 & 0.0 & 0.5 & 0.4 & 36. & n & & 0. & 0. & 0. & $<1$ & $<1$ & $<$ & & $<$ & $<10$ & $<5$ & $<1$ & $<1.5$ \\
\hline $58-2,97-98$ & 69 & & & & 1 & 0 & 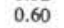 & & 33 & & & 0. & 0. & 0. & 1 & $<$ & $<$ & 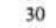 & $<1$ & $<10$ & $<5$ & $<1$ & $<1.5$ \\
\hline $59-1,65-67$ & 11 & & & & 1. & & & & & & & & & & $<1$ & $<10$ & $<$ & & $<1$ & $<10$ & $<5$ & $<1$ & $<1.5$ \\
\hline $60-1,75-78$ & .55 & 15.8 & & 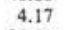 & & & 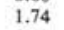 & & 3 & & & 5. & 0. & 0. & 1 & 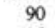 & 2 & 13 & 7 & 0 & 8 & 1.4 & 1.6 \\
\hline 87 & & & & & & & & & & & & 1. & 0. & & & 15 & & & $<1$ & $<10$ & $<5$ & $<1$ & $<1.5$ \\
\hline-28 & 72 & & & & 2. & 0. & & & 3 & $\pi$ & & $0 . c$ & 0.0 & 0. & 11 & 11 & $<1$ & $<20$ & $<1$ & $<10$ & $<5$ & $<1$ & $<1.5$ \\
\hline $1,15-16$ & t & & & & 1. & & & & & 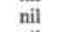 & & 0.5 & $\mathrm{tr}$ & & $<1$ & 11 & $<$ & $<20$ & $<$ & & $<5$ & $<1$ & $<1.5$ \\
\hline $63-1,104-105$ & 12.99 & & & 4 & 0 & & 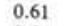 & & 37. & & & 0. & 0. & & $<1$ & $<10$ & $<$ & $<$ & $<$ & $<10$ & $<5$ & $<1$ & $<1.5$ \\
\hline 828 & 980 & & & 4 & & & & & & nil & & 0. & & & & & & $<$ & $<$ & $<10$ & $<5$ & $<1$ & $<1.5$ \\
\hline 1, 30-31 & 14.02 & & & 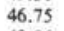 & 0 & & & & & n & & 0. & & & $<$ & $<1$ & $<15$ & $<20$ & $<$ & $<10$ & $<5$ & $<1$ & $<1.5$ \\
\hline & & & & & & & & & & & & & & & & & & & $<$ & $<10$ & $<5$ & $<1$ & $<1.5$ \\
\hline-27 & & & & & & & & & & & & & 0. & 0. & $<1$ & $<10$ & $<15$ & $<20$ & $<$ & $<10$ & $<5$ & $<1$ & $<1.5$ \\
\hline 16 & & & & & & & & & & s & & & & & & - & & & $<$ & $<10$ & $<$ & $<1$ & $<1.5$ \\
\hline s & & & & & 0.8 & & & & & 2.1 & & & & & & 93 & & & 52 & 11 & $<5$ & 1.4 & 7.5 \\
\hline 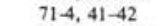 & & & & & : & & & & & 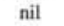 & & & & & $<$ & $<1$ & $<1$ & $<$ & $<10$ & $<10$ & $<5$ & $<1$ & $<1.5$ \\
\hline-10 & s & & & & & & & & 15.25 & $\mathrm{n}$ & & 0.51 & 0.06 & & is & 11 & & $\tilde{z}_{2}$ & $<$ & $<$ & $<5$ & $<1$ & $<1.5$ \\
\hline & & & & & & & & & & & & & & & & & & & & & $<$ & $<$ & \\
\hline 70 & . & 1.59 & & & & 0. & & & 16 & & & & & & $<$ & 10 & 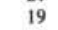 & $<20$ & $<$ & $<10$ & $<5$ & $<1$ & $<1.5$ \\
\hline & & & & & & & & & & & & & & & $<$ & $<$ & $<$ & & & & $<5$ & $<1$ & $<1.5$ \\
\hline & 15.76 & & & & 0. & 0. & & 0. & 35 & n & & 0.2 & 0. & & $<10$ & $<10$ & $<15$ & $<10$ & $<$ & $<10$ & $<5$ & $<1$ & $<1.5$ \\
\hline 27 & & & & & & & & & & & & 0. & & & 10 & $<$ & $<1$ & $<20$ & $<$ & $<10$ & $<5$ & $<1$ & $<1.5$ \\
\hline & 18 & & & & & 0. & & & & $\cdots$ & 0. & 0.7 & 0. & & 1 & $<$ & 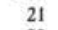 & 22 & $<$ & $<10$ & $<5$ & $<1$ & $<1.5$ \\
\hline $83-1,8$ & & & & & & & & & & in & & 0. & 0. & & is & $<$ & 2 & 20 & $<10$ & $<10$ & $<5$ & $<1$ & 1.6 \\
\hline $85-1,100-101$ & 7.50 & 0.39 & 0.27 & 50.71 & 0.58 & 0.02 & 0.47 & 0.14 & 40.30 & nil & 0.04 & 0.19 & 0.02 & 0.02 & 10 & $<10$ & $<15$ & $<20$ & $<10$ & $<10$ & $<5$ & $<1$ & $<1.5$ \\
\hline
\end{tabular}

indicates that it is represented by organic matter and associated heavy metals. The assemblage manifests itself most distinctly in lower Aptian tuffaceous limestones enriched in organic matter, and in Coniacian to upper Turonian sediments $(27-1,111-120 \mathrm{~cm})$. The structure of the assemblage concerned is also rather distinct in other intervals of the section (lower Maastrichtianlower Eocene). Organic carbon, however, is omitted. It is assumed that this is the level where the Mesozoic/ Cenozoic unconformable boundary lies (with a considerable hiatus of about 14 m.y.) (Samples 8-2, 54-56 cm; 7-1, 61-63 cm; Fig. 1).

\section{CHEMICAL ANALYSES RECALCULATED TO}

\section{A MINERAL-FREE BASIS (Tables 4, 5, 6; Fig. 2)}

Assemblage IA (+): $\mathbf{M g O}(0.37)-F e(0.35)$. The assemblage concerned corresponds to the phases containing extra amounts of $\mathrm{Mg}$ and $\mathrm{Fe}$ with respect to the median composition of the lithosphere. It is most distinctly manifested in red (pink, brown) lower Albian to upper Aptian limestones (Samples 60-1, 75-78 cm; 60-4, 11-62 $\mathrm{cm})$, enriched in altered volcaniclastic material of basic to median composition, and hydrous ferric oxides scattered in the carbonate mass (Fig. 2). This assemblage also occupies the interval enriched in basic volcaniclastic material with hydrous ferric oxides: the middle Albian to Coniacian-upper Turonian and lower Aptian tuffaceous limestones.

Assemblage IB (-): $\mathrm{Na}_{2} \mathrm{O}(-0.58)-\mathrm{P}(-0.82)-\mathrm{Cu}$ $(-0.35)-\mathrm{Co}(-0.56)-\mathrm{Pb}(-0.95)-\mathrm{Ga}(-0.89)-\mathrm{Mo}$ $(-\mathbf{0 . 7 9 )}$. The set of components concerned most likely is represented by phosphate compounds of the given heavy metals, formed in the process of volcaniclastic transformation into clay phases. Several distinctly separated intervals of the assemblage should be noted; the lower beds of upper Barremian olive-gray limestones; upper Aptian-middle Albian multicolored limestones; and lower Eocene-Pleistocene foraminifer-nannofossil micritic oozes (Fig. 2).

Assemblage IIA (+): $\mathrm{Cr}(0.96)-\mathrm{Ni}(0.92)-\mathrm{V}(0.93)-\mathrm{Cu}$ (0.40)-Co(0.45)-Ge(0.44). The mineral nature of this assemblage of heavy metals is not evident. However, its most distinct manifestations are found predominantly at the same levels as the aforementioned assemblages, 
Table 2. Results of factor analysis (R-mode) for chemical components (wt.\%), Cenozoic-Mesozoic sediments of the northwest Pacific, DSDP Site 463.

\begin{tabular}{|c|c|c|c|c|}
\hline \multirow[b]{2}{*}{ No. } & \multirow[b]{2}{*}{ Component } & \multicolumn{3}{|c|}{$\begin{array}{l}\text { Factor Loading } \\
\text { (after rotation) }\end{array}$} \\
\hline & & I & II & III \\
\hline 1 & $\mathrm{SiO}_{2}$ & 0.09 & -0.89 & \\
\hline 2 & $\mathrm{Al}_{2} \mathrm{O}_{3}$ & 0.29 & -0.71 & 0.14 \\
\hline 3 & $\mathrm{CaO}$ & -0.42 & 0.64 & 0.48 \\
\hline 4 & $\mathrm{MgO}$ & 0.18 & -0.52 & 0.17 \\
\hline 5 & $\mathrm{Na}_{2} \mathrm{O}$ & 0.53 & 0.61 & \\
\hline 6 & $\mathrm{~K}_{2} \mathrm{O}$ & 0.57 & -0.63 & 0.06 \\
\hline 7 & $\mathrm{CO}_{2}$ & -0.38 & 0.61 & 0.56 \\
\hline 8 & C & 0.34 & 0.13 & -0.69 \\
\hline 9 & $\mathrm{Fe}$ & 0.45 & -0.63 & \\
\hline 10 & $\mathrm{Mn}$ & & -0.24 & -0.36 \\
\hline 11 & $\mathrm{P}$ & & & \\
\hline 12 & $\mathrm{Cr}$ & 0.93 & -0.23 & \\
\hline 13 & $\mathrm{Ni}$ & 0.85 & & -0.44 \\
\hline 14 & V & 0.90 & & \\
\hline 15 & $\mathrm{Cu}$ & 0.82 & & \\
\hline 16 & Co & 0.84 & -0.10 & -0.46 \\
\hline 17 & $\mathrm{~Pb}$ & & & -0.57 \\
\hline 18 & $\mathrm{Ga}$ & 0.67 & & 0.14 \\
\hline 19 & $\mathrm{Ge}$ & 0.57 & & \\
\hline 20 & Mo & 0.13 & & -0.86 \\
\hline \multicolumn{2}{|c|}{$\begin{array}{l}\text { Input in } \\
\text { dispersion (\%) }\end{array}$} & 42.0160 & 12.6815 & 9.9708 \\
\hline \multicolumn{2}{|c|}{ Total } & 42.0160 & 54.7055 & 64.6763 \\
\hline
\end{tabular}

IA ( +$)$ and IB ( $(-)$, represented by altered products of basic volcaniclastic material (Fig. 2).

Assemblage IIB (-): $\mathrm{K}_{2} \mathrm{O}(-0.29)-\mathrm{P}(-0.32)$. The assemblage distribution is limited to the intervals with a distinct abundance of $\mathrm{K}$ containing clayey minerals: $\mathrm{K}$-smectites, mixed-layer illite-montmorillonite, and illite proper, formed after basic volcaniclastic material. The assemblage of components concerned is represented by phosphorus compounds, adsorbed by K-bearing clay minerals. The interval with this assemblage is distinctly manifested in the section: the upper Barremian-lower Albian, a few manifestations being found in the lower Maastrichtian and Pleistocene (Fig. 2).

Assemblage IIIA (+): $\mathrm{MgO}(0.24)-\mathrm{K}_{2} \mathrm{O}(0.53)-\mathrm{Cu}$ $(0.70)-\mathrm{Co}(0.57)-\mathrm{Ge}(0.66)$. The set of components clearly shows that this assemblage is represented by a specific variety of K-bearing clay minerals developed from basic and median volcaniclastic material. The sequence has two distinct maxima: the olive-gray lower Barremian limestones, and the multicolored upper Aptian-lower Albian limestones (Fig. 2).

Assemblage IIIB (-): $\mathrm{CaO}(-0.81)-\mathrm{Fe}(-0.72)-\mathrm{Mn}$ $(-\mathbf{0 . 7 3})$. The mineral nature of this assemblage is not amenable to a reliably definite interpretation. It monotonously occurs in upper Albian-upper Miocene sediments and, to a lesser degree, in the upper Barremian-lower Aptian rocks. Its absence in red deposits containing hydrous $\mathrm{Fe}$ and $\mathrm{Mn}$ oxides permits exclusion of its hydroxide composition and suggests the presence of a $\mathrm{Fe}, \mathrm{Mn}, \mathrm{Ca}$-smectitic phase in the basic volcaniclastic materials, and a silicate admixture in the carbonate sediments.
Table 3. Stratigraphic distribution of factor scores (R-mode) for chemical components (wt.\%) in Cenozoic-Mesozoic sediments of the northwest Pacific, DSDP Site 463.

\begin{tabular}{|c|c|c|c|c|c|}
\hline \multirow[b]{2}{*}{ No. } & \multirow{2}{*}{$\begin{array}{c}\text { Sample } \\
\text { (interval in } \mathrm{cm} \text { ) }\end{array}$} & \multirow[b]{2}{*}{ Age } & \multicolumn{3}{|c|}{$\begin{array}{c}\text { Factor Score } \\
\text { (after rotation) }\end{array}$} \\
\hline & & & 1 & II & III \\
\hline 1 & $463-1-1,70-72$ & Pleistocene & 0.29 & -0.51 & 0.55 \\
\hline 2 & $3-2,48-50$ & Lower Pliocene & -0.02 & 0.35 & 0.25 \\
\hline 3 & $4-3,20-22$ & Upper Miocene & 0.05 & 0.26 & 0.31 \\
\hline 4 & $5-1,63-65$ & Upper Oligocene & -0.02 & 1.65 & -0.35 \\
\hline 5 & $6-3,59-61$ & Upper Oligocene & -0.07 & 0.63 & 0.76 \\
\hline 6 & $7-1,61-63$ & Lower Eocene & -0.45 & 1.64 & -0.83 \\
\hline 7 & $8-2,54-56$ & Upper Maastrichtian & -1.49 & $-2,41$ & -3.96 \\
\hline 8 & $8-3,34-36$ & Upper Maastrichtian & 0.19 & 1.02 & 0.40 \\
\hline 9 & $9-1,30-32$ & Upper Maastrichtian & 0.10 & 0.26 & 0.67 \\
\hline 10 & $10-1,78-80$ & Upper Maastrichtian & 0.09 & 0.23 & 0.47 \\
\hline 11 & $11-1,72-74$ & Upper Maastricntian & -0.26 & 0.61 & -0.14 \\
\hline 12 & $12-1,30-32$ & Upper Maastrichtian & -0.38 & 1.00 & -0.44 \\
\hline 13 & $13-1,72-74$ & Upper Maastrichtian & 0.38 & 1.38 & 0.41 \\
\hline 14 & $14-1,84-86$ & Upper Maastrichtian & 0.44 & 1.50 & 0.47 \\
\hline 15 & $15-2,70-72$ & Lower Maastrichtian & -0.01 & 0.50 & 0.45 \\
\hline 16 & $16-2,80-82$ & Lower Maastrichtian & 0.29 & 1.25 & 0.27 \\
\hline 17 & $17-1,86-88$ & Lower Maastrichtian & 0.32 & 1.32 & 0.34 \\
\hline 18 & $19-1,70-72$ & Lower Maastrichtian & -0.17 & -0.23 & 1.09 \\
\hline 19 & $20-1,70-72$ & Lower Maastrichtian & 0.31 & 1.28 & 0.26 \\
\hline 20 & $21-1,70-72$ & Upper Campanian & -0.21 & 1.35 & -0.30 \\
\hline 21 & $22-2,121-123$ & Upper Campanian & 0.29 & 1.40 & 0.15 \\
\hline 22 & $24-1,93-95$ & Upper Campanian & -0.23 & 0.43 & -0.003 \\
\hline 23 & $25-1,23-25$ & Upper Campanian & 0.12 & 0.94 & 0.13 \\
\hline 24 & $26-1,118-120$ & Upper Campanian- & -0.01 & 1.31 & -0.13 \\
\hline 25 & $27-1,118-120$ & Coniacian to Upper Turonian & 0.05 & 1.31 & -1.22 \\
\hline 26 & $30-1,100-102$ & Coniacian to Upper Turonian & -0.44 & 0.36 & -0.09 \\
\hline 27 & $33-1,61-63$ & Middle Turonian & -0.01 & 0.59 & -0.05 \\
\hline 28 & $34-1,32-34$ & Middle Turonian & -0.12 & -0.67 & 0.51 \\
\hline 29 & $38-1,40-41$ & Lower Turonian & -0.19 & 0.29 & 0.06 \\
\hline 30 & $43-1,50-51$ & Middle-lower Cenomanian & -0.12 & 1.05 & -0.19 \\
\hline 31 & $48-1,64-66$ & Upper Albian & 0.15 & -0.31 & -0.004 \\
\hline 32 & $50-1,64-65$ & Upper Albian & -0.01 & -0.29 & 0.05 \\
\hline 33 & $55-1,4-5$ & Lower-upper Albian & -0.56 & -1.10 & -0.03 \\
\hline 34 & $56-1,35-36$ & Lower-upper Albian & -0.53 & 0.06 & -0.08 \\
\hline 35 & $57-1,22-23$ & Lower-upper Albian & 0.04 & -0.60 & 0.58 \\
\hline 36 & $58-2,97-98$ & Lower-upper Albian & 0.01 & -1.09 & 0.56 \\
\hline 37 & $59-1,65-67$ & Lower-upper Albian & -0.38 & -0.31 & 0.06 \\
\hline 38 & $60-1,75-78$ & Lower-upper Albian & 6.31 & -1.54 & 1.05 \\
\hline 39 & $60-4,81-82$ & Lower-upper Albian & 0.79 & -1.33 & 1.58 \\
\hline 40 & $61-1,27-28$ & Lower-upper Albian & -0.22 & -0.85 & 0.40 \\
\hline 41 & $62-1,15-16$ & Lower-upper Albian & -0.10 & -0.88 & 0.48 \\
\hline 42 & $63-1,104-105$ & Lower-upper Albian & -0.34 & -0.32 & 0.14 \\
\hline 43 & $64-2,82-84$ & Lower-upper Albian & -0.49 & -0.06 & -0.02 \\
\hline 44 & $65-1,30-31$ & Lower-upper Albian & -0.91 & -0.55 & -0.31 \\
\hline 45 & $66-3,16-18$ & Lower Aptian & -0.09 & -1.01 & 1.10 \\
\hline 46 & $67-1,25-27$ & Lower Aptian & -0.31 & -0.58 & 0.31 \\
\hline 47 & $69-3,15-16$ & Lower Aptian & -0.46 & -1.59 & -0.13 \\
\hline 48 & $70-5,99-100$ & Lower Aptian & 2.94 & 0.34 & -5.32 \\
\hline 49 & $71-4,41-42$ & Lower Aptian & -0.48 & -0.53 & -0.18 \\
\hline 50 & $72-2,104-105$ & Lower Aptian & -0.45 & -1.43 & -0.29 \\
\hline 51 & $73-3,18-19$ & Lower Aptian & -0.06 & -1.55 & 0.03 \\
\hline 52 & $74-1,69-70$ & Lower Aptian & -0.27 & -1.45 & 0.03 \\
\hline 53 & $75-1,78-79$ & Lower Aptian & -0.76 & 0.35 & -0.44 \\
\hline 54 & $77-1,0-1$ & Lower Aptian & -0.97 & -0.27 & -0.25 \\
\hline 55 & $81-1,26-27$ & Upper Barremian & -0.49 & -0.44 & 0.10 \\
\hline 56 & $82-1,25-26$ & Upper Barremian & -0.56 & -1.33 & -0.19 \\
\hline 57 & $83-1,86-87$ & Upper Barremian & -0.07 & -1.22 & 0.15 \\
\hline 58 & $85-1,100-101$ & Upper Barremian & -0.47 & -0.23 & 0.77 \\
\hline
\end{tabular}

\section{AVERAGE CONTENTS AND ACCUMULATION RATES OF COMPONENTS (Tables 7 and 8; Figs. 3-5)}

\section{Distribution of Average Contents}

In the preceding section, the distribution of components for definite samples of the section and the forms of their occurrence were shown. Average contents have been calculated for the main geochronological subdivisions to outline the general tendencies of geochemical history. Where stratigraphic intervals are composed of heterogenous sediments (e.g., lower Aptian), the average content was calculated for each major lithologic type.

Examination of features of distribution of component average contents (Tables 7 and 8; Figs. 3 and 4) with regard to peculiarities in distribution of their particular values in the studied section allow us to identify three main geochemical stages: (1) Lower Cretaceous 
(upper Barremian-middle Albian), (2) Upper Cretaceous (upper Albian-upper Maastrichtian); (3) Cenozoic (lower Eocene-Pleistocene).

Lower Cretaceous stage. This stage is distinguished by accumulation of sediments with a relatively low content of $\mathrm{CaCO}_{3}$ (as a rule, not more than $82 \%$ ), and relatively high amounts of $\mathrm{SiO}_{2}, \mathrm{Al}_{2} \mathrm{O}_{3}, \mathrm{Fe}, \mathrm{Mn}$, and heavy metals. It should be noted that the intervals with high concentrations of $\mathrm{SiO}_{2}, \mathrm{Al}_{2} \mathrm{O}_{3}, \mathrm{Fe}$, and $\mathrm{Mn}$ were found in carbonate deposits enriched in basic volcaniclastic material and hydrous $\mathrm{Fe}$ - and Mn-oxides: lower Aptian tuffaceous limestones rich in sapropelic organic matter, and lower Aptian-middle Albian multicolored limestones. This specific feature is particularly well manifested by data recalculated to a mineral-free basis (Fig. 4), showing the ferromagnesian composition of components and products of their illitization (enrichment of $\mathrm{K}_{2} \mathrm{O}$ ). The distinctly expressed epigenetic transformation of upper Albian-middle Albian multicolored limestones should be emphasized: recrystallization of $\mathrm{CaCO}_{3}$ formed at the expense or alteration of volcaniclastic material, and $\mathrm{MnCO}_{3}-\mathrm{FeCO}_{3}-\mathrm{MgCO}_{3}$, frequently identified under the microscope and on X-ray diffractograms and determined by normative recalculations of chemical analyses (Fig. 3).

Upper Cretaceous stage. The $\mathrm{CaCO}_{3}$ content in the sediments concerned, represented by almost pure chalk (foraminifer-nannofossil micritic and nannofossil-foraminifer), usually exceeds $85 \%$, with rather lower contents of $\mathrm{Al}_{2} \mathrm{O}_{3}, \mathrm{Fe}$, and $\mathrm{Mn}$ (Fig. 3). Appreciable amounts of volcaniclastics altered to smectite-illite and hydrous ferric oxide can be estimated by the contents recalculated to a mineral-free basis (Fig. 4), and by the data on distribution of mineral phases given above.

Cenozoic stage. The $\mathrm{CaCO}_{3}$ content in these sediments, composed mainly of foraminifer-nannofossil micritic oozes, is usually about $90 \%$. It is of interest that the deposits directly overlying the considerable hiatus in sedimentation (lower Eocene-upper Maastrichtian; upper Oligocene-middle Eocene; upper Miocene-upper Oligocene) have relatively high $\mathrm{Mn}$ and $\mathrm{P}$ contents (Figs. 3 and 4), the latter in accordance with the presence of remains from sediment dissolution (Mn-hydroxides and phosphates).

\section{Distribution of Average Rates of Component Accumulation}

Updated shipboard data on stratigraphic subdivision of the section, as well as the chronostratigraphic and magnetic-stratigraphic scales adopted by the shipboard scientists (Berggren, 1973; Geol. Soc. of London, 1964; Hardenbol and Berggren, 1978; Larson and Hilde, 1975; Van Eysinga, 1975; van Hinte, 1976) were applied for calculation of average rates of component accumulation within the main geochronological intervals. The rather tentative and approximate nature of these data is quite obvious; however, their application together with all available geological and lithologic information allows us to throw light upon a number of aspects of the geochemical history of sedimentation.
Shipboard data on wet-bulk density and water contents of sediments, as well as the mean value of component contents for a given geochronological interval (Tables 7 and 8), were used for calculation of values of accumulation rates in weight units per air-dry weight $\left(\mathrm{mg} \cdot \mathrm{cm}^{-2} \cdot 10^{-3} \mathrm{yr}^{-1}\right)$.

The following conclusions can be drawn from the data presented in Tables 7 and 8 and Figure 5:

\section{Average Linear Rates of Sedimentation}

Analysis of the distribution of average linear rates of sedimentation took into account the lithologic and facies nature of the sediments, as well as the fact that the Hole 463 section, as a whole, is composed of carbonate deposits that accumulated above the carbonatecompensation depth (CCD). Three groups of values have been distinguished: (1) maximum, more than 40 $\mathrm{mm} \cdot 10^{-3} \mathrm{yr}^{-1}$; (2) median, $10-40 \mathrm{~mm} \cdot 10^{-3} \mathrm{yr}^{-1}$; (3) low, less than $10 \mathrm{~mm} \cdot 10^{-3} \mathrm{yr}^{-1}$.

The maximum rates of sedimentation were observed in the late Barremian-early Aptian.

It should be noted that upper Barremian-lower Aptian sediments are represented by limestones considerably enriched with volcaniclastic material and clastic products of destruction of relatively shallow-water reefbuilding and bioherm remnants. Accumulation of these sediments occurred in a relative shallow basin, distinguished in the early Aptian by stagnant conditions: accumulations of tuffaceous carbonate sediments enriched in sapropelic material, plant detritus, and gray calcareous sediments. Minimum rates of accumulation evaluated for these deposits are in the range from 41.2 to $44.0 \mathrm{~mm} \cdot 10^{-3} \mathrm{yr}^{-1}$, such values are also known in a number of Recent Pacific basins with volcanic reefs and rather dissected bottom topography (Bezrukov and Romankevich, 1970; Lisitzin, 1974, 1978).

Cenozoic deposits and sediments of late Santonian, late Campanian to middle Turonian, and middle to late Albian are generally characterized by low rates of sedimentation. Bearing in mind the relatively high position of the CCD and the considerable erosional role of bottom currents (particularly for the early Eocene and early Oligocene), and accumulation of sediments below the lysocline, it may be concluded that in the Cenozoic (definitely since the late Miocene) sedimentation took place in the northern oligotropic zone of the Pacific. This zone was of relatively low biological productivity, with depths of the lysocline and CCD similar to Recent ones.

Middle transitional values of sedimentation rates are typical of the intervals between the late Aptian to early Albian and early Cenomanian to early Turonian. The development of the region in these periods was presumably during a period of ocean-bottom subsidence and basin deepening.

\section{Accumulation Rate of Components}

$\mathrm{CaCO}_{3}$ is the main component of the sediments. Its distribution, as a whole, is proportional to average rates of sedimentation. However, an interpretation of $\mathrm{CaCO}_{3}$ 


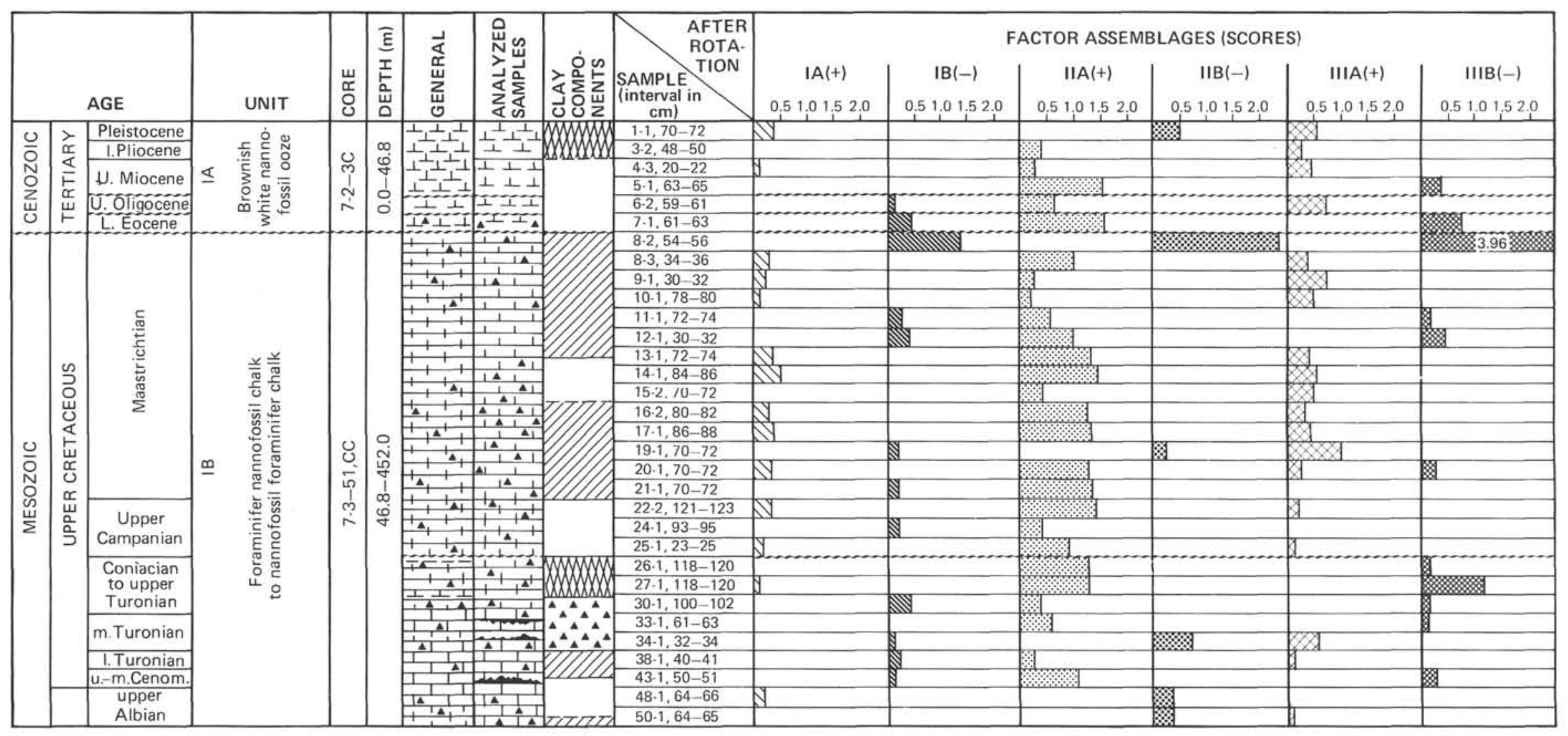




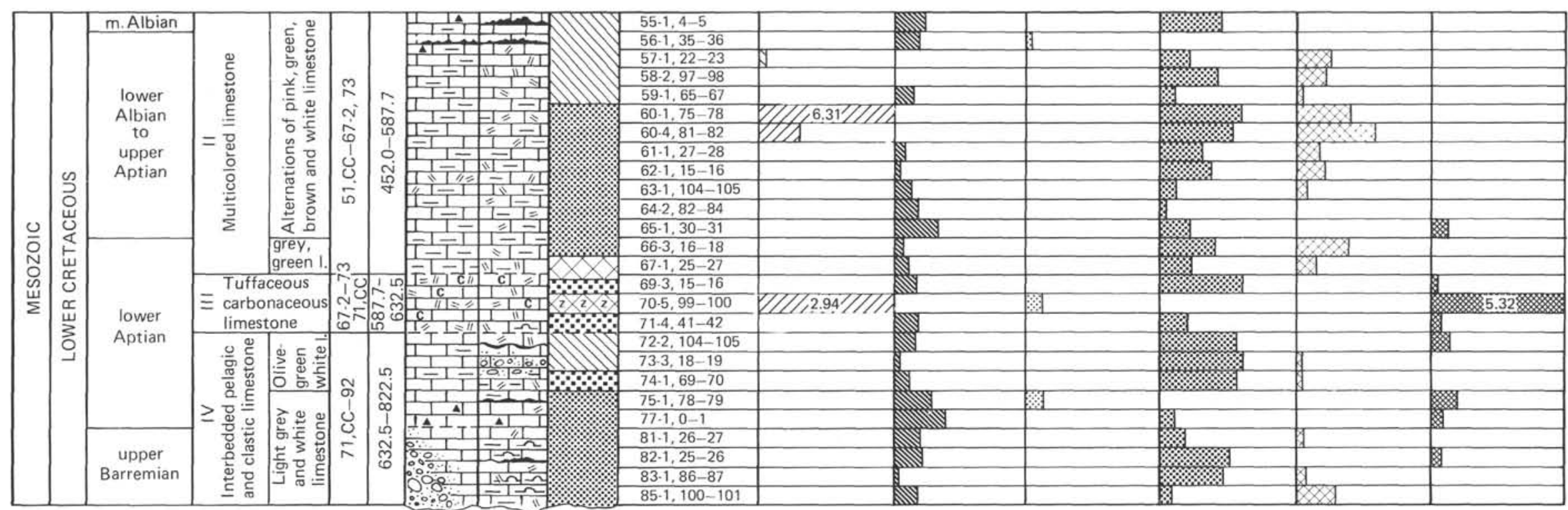

CLAY COMPONENTS

Mixed-layered montmorillonite-illite
phase $(\mathrm{M}-1)$ with little admixture

Cristobalie and tridymite
I (DISPERSION 42.02\%)

$A(+)$

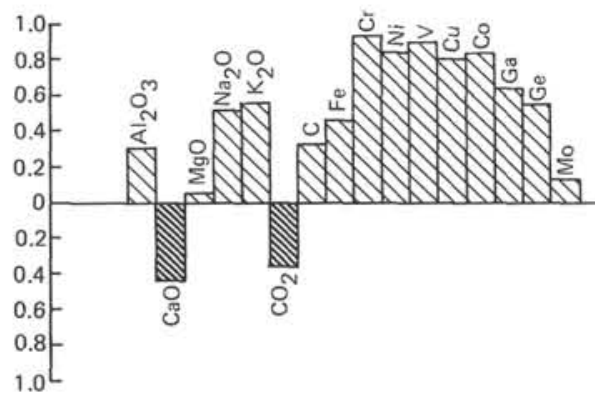

$B(-)$
II (DISPERSION 12.69\%)

$A(+)$

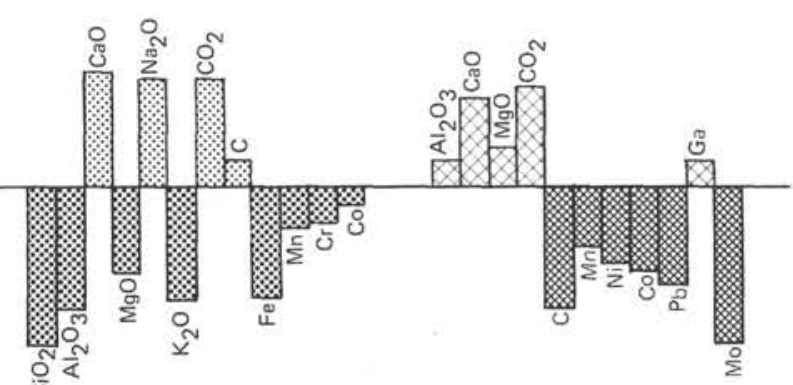

Figure 1. Stratigraphic distribution of factor scores for the main paragenetic assemblages of chemical components in the post-Jurassic sedimentary section of the central northwest Pacific, western Mid-Pacific Mountains, DSDP Site 463 (data on chemical analysis recalculated to air-dry weight). Lithological symbols are those used in the DSDP reports. Clay components: 1) mixed-layered montmorillonite-illite phase (M-I) with little admixture; 2) montmorillone-zeolite assemblage after basic volcanoclastic material; 3) illite with admixture of mixed-layered, illite-montmorillonite phase (I-M); 4) illite admixed with chlorite; 5) illite admixed with mont morillonite; 6) mixed-layered phase of montmorillonite-illite with zeolite; 7) cristobalite and 
Table 4. Chemical composition of Mesozoic-Cenozoic sediments, northwestern Pacific, western Mid-Pacific Mountains, DSDP Site 463.

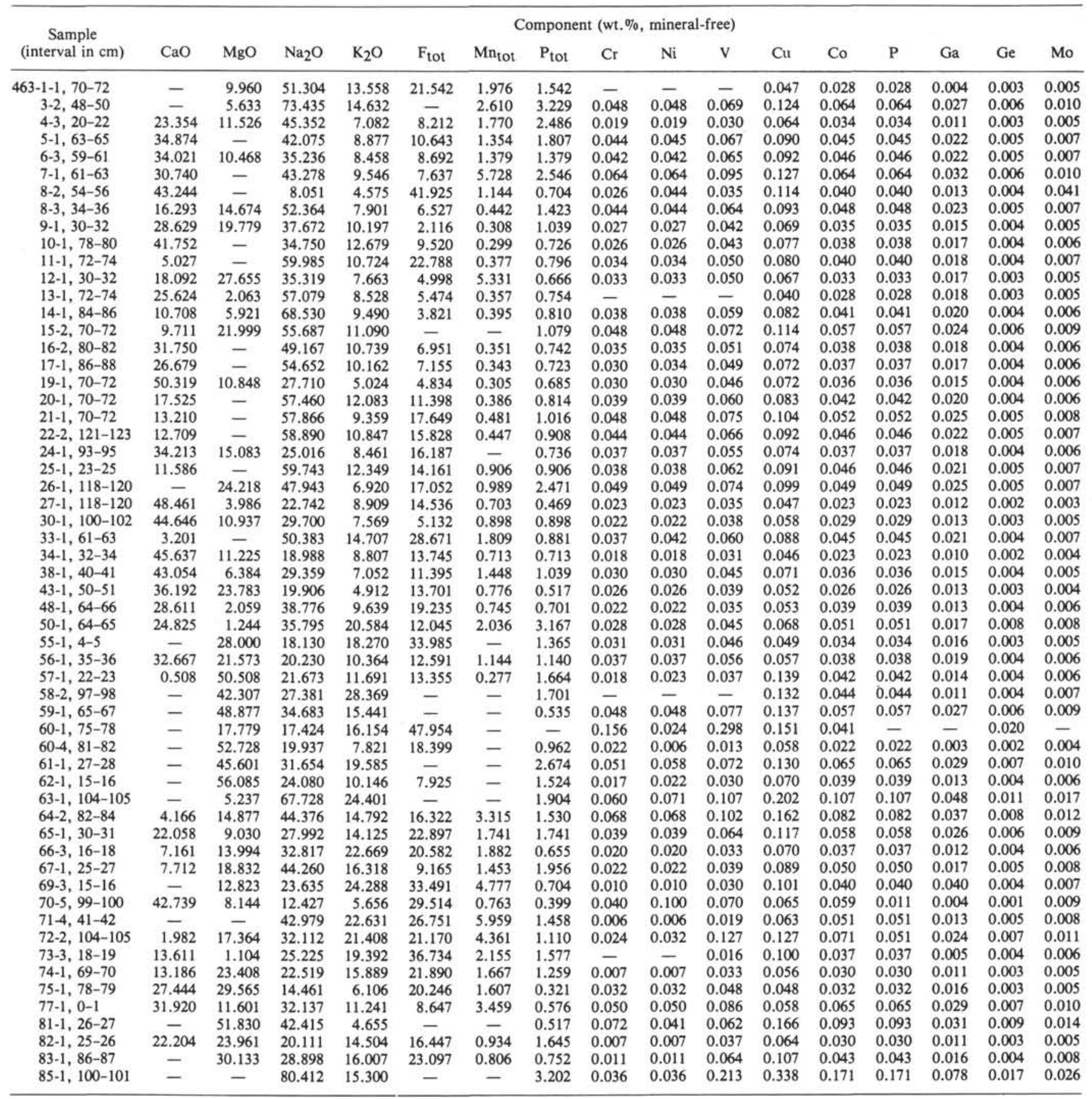

accumulation rates should take into account the faciesgenetic type of the sediment. High rates of $\mathrm{CaCO}_{3}$ accumulation in the early Barremian-early Aptian deposits $\left(6230-7119 \mathrm{mg} \cdot \mathrm{cm}^{-2} \cdot 10^{-3} \mathrm{yr}^{-1}\right)$ were governed not so much by the biological productivity of the basin, but mostly by redeposition, underwater sliding, slumping, etc., of relatively shallow-water carbonate sediments, clastic products resulting from destruction of reef and bioherm formations. Unlike Lower Cretaceous deposits, lower Maastrichtian sediments are predominantly calcareous accumulations of foraminifer and nannofossil skeletons deposited in the equatorial zone of high biological productivity above the CCD (van Andel et al., 1974, 1975, 1976).

Maximum amounts of $\mathrm{SiO}_{2}, \mathrm{Al}_{2} \mathrm{O}_{3}, \mathrm{Fe}$, and $\mathrm{Mn}$ accumulated during the late Barremian-early Aptian, as a result of pronounced volcanic processes. The components were contributed to the sediments mainly in the form of mafic aluminosilicate material and, to a lesser degree, as hydrothermal exhalations. Manganese might indicate the supply from the exhalation sources. The rate of $\mathrm{Mn}$ accumulation in recent pelagic oceanic sediments ranges from 0.2 to $4.0 \mathrm{mg} \cdot \mathrm{cm}^{-2} \cdot 10^{-3} \mathrm{yr}^{-1}$ (Bender et al., 1970; Riley and Chester, 1971). 
Table 5. Results of the Factor analysis (R-mode) of chemical components (MB); Cenozoic and Mesozoic sediments of the North-West Pacific, DSDP Leg 62, Site 463.

\begin{tabular}{ccccc}
\hline & & \multicolumn{3}{c}{ Factor Loading (after rotation) } \\
\cline { 4 - 5 } No. & Component & I & II & III \\
\hline 1 & $\mathrm{CaO}$ & & 0.18 & -0.81 \\
2 & $\mathrm{MgO}$ & 0.37 & & 0.24 \\
3 & $\mathrm{Na} 2 \mathrm{O}$ & -0.58 & & \\
4 & $\mathrm{~K} 2 \mathrm{O}$ & & -0.29 & 0.53 \\
5 & $\mathrm{Fe}$ & 0.35 & -0.05 & -0.72 \\
6 & $\mathrm{Mn}$ & & & -0.73 \\
7 & $\mathrm{P}$ & -0.82 & -0.32 & -0.11 \\
8 & $\mathrm{Cr}$ & -0.001 & 0.96 & \\
9 & $\mathrm{Ni}$ & -0.20 & 0.92 & \\
10 & $\mathrm{~V}$ & -0.05 & 0.93 & 0.70 \\
11 & $\mathrm{Cu}$ & -0.35 & 0.40 & 0.57 \\
12 & $\mathrm{Co}$ & -0.56 & 0.45 & 0.12 \\
13 & $\mathrm{~Pb}$ & -0.95 & -0.01 & 0.10 \\
14 & $\mathrm{Ga}$ & -0.85 & & 0.66 \\
15 & $\mathrm{Ge}$ & -0.22 & 0.44 & 0.20 \\
16 & $\mathrm{Mo}$ & -0.79 & & \\
Input in & & & & \\
dispersion (\%) & 35.0247 & 18.2472 & 16.2391 \\
\multicolumn{7}{l}{$\begin{array}{l}\text { Total } \\
\text { dispersion (\%) }\end{array}$} & 35.0247 & 53.2719 & 69.5110 \\
\hline
\end{tabular}

The accumulation rate of $\mathrm{Mn}$ in the East Pacific Rise sediments is 24 to $35 \mathrm{mg} \cdot \mathrm{cm}^{-2} \cdot 10^{-3} \mathrm{yr}^{-1}$ (Boström, 1973; Bender et al., 1971; Lyle, 1976).

Rates of Mn accumulation during the Early Cretaceous (early Barremian-early Aptian) exceeded $1.9 \mathrm{mg}$. $\mathrm{cm}^{-2} \cdot 10^{-3} \mathrm{yr}^{-1}$. Lower Aptian tuffaceous calcareous sediments, enriched in organic detritus, have intervals with the highest rates of accumulation: $8.10 \mathrm{mg} \cdot \mathrm{cm}^{-2}$. $10^{-3} \mathrm{yr}^{-1}$. The same geological interval is distinguished by rather high rates of $\mathrm{Fe}$ accumulation: 65.2 to 96.8 $\mathrm{mg} \cdot \mathrm{cm}^{-2} \cdot 10^{-3} \mathrm{yr}^{-1}$. For East Pacific Rise sediments (Boström, 1973; Bender et al., 1971), iron accumulates at 63 to $110 \mathrm{mg} \cdot \mathrm{cm}^{-2} \cdot 10^{-3} \mathrm{yr}^{-1}$. The forms of contributed components were discussed in the previous section. Besides hydroxide and silicate forms of heavy metals, a certain role belongs to organic matter, concentrating metals of hydrothermal origin from the sea water. The significance of dilution by carbonate components should be kept in mind when comparing concentration data with accumulation rates (see distribution of $\mathrm{Fe}$ and $\mathrm{Mn}$ concentrations recalculated to a mineral-free basis, in Figure 4). Also, the calculated average rates of accumulation of components for the sediments concerned can be compared to those of other regions, disclosing generally high rates of sedimentation during initial stages in development of the Mid-Pacific Mountains.

The relatively high accumulation rates of the components concerned in the early Maastrichtian have a different nature. With relatively low concentrations of $\mathrm{SiO}_{2}, \mathrm{Al}_{2} \mathrm{O}_{3}, \mathrm{Fe}, \mathrm{Mn}$, etc., they are dominated by rather high rates of biogenic ooze sedimentation in the equatorial zone of high biological productivity (Figs. 3-5).

High rates of phosphorus accumulation also have a dual nature: in the late Barremian-middle Albian, they resulted from volcanic activity (see forms of phos-
Table 6. Stratigraphic distribution of factor scores (Rmode) for chemical components (mineral-free) in Cenozoic-Mesozoic sediments, central northwest $\mathrm{Pa}$ cific, DSDP Site 463.

\begin{tabular}{|c|c|c|c|c|}
\hline \multirow[b]{2}{*}{ No. } & \multirow{2}{*}{$\begin{array}{c}\text { Sample } \\
\text { (interval in } \mathrm{cm} \text { ) }\end{array}$} & \multicolumn{3}{|c|}{$\begin{array}{c}\text { Factor Scores } \\
\text { (after rotation) }\end{array}$} \\
\hline & & I & II & III \\
\hline 1 & $463-1-1,70-72$ & 0.38 & -3.31 & 0.25 \\
\hline 2 & $3-2,48-50$ & -1.11 & 0.18 & 1.07 \\
\hline 3 & $4-3,20-22$ & -0.02 & -0.38 & -0.87 \\
\hline 4 & $5-1,63-65$ & -0.62 & 0.64 & -0.78 \\
\hline 5 & $6-3,59-61$ & -0.28 & 0.54 & -0.49 \\
\hline 6 & $7-1,61-63$ & -1.24 & 1.02 & -0.63 \\
\hline 7 & $8-2,54-56$ & -0.38 & 0.67 & -1.06 \\
\hline 8 & $8-3,34-36$ & -0.38 & 0.55 & -0.33 \\
\hline 9 & $9-1,30-32$ & 0.22 & 0.0004 & -0.34 \\
\hline 10 & $10-1,78-80$ & -0.10 & 0.17 & -0.56 \\
\hline 11 & $11-1,72-74$ & -0.34 & 0.34 & -0.56 \\
\hline 12 & $12-1,30-32$ & 0.27 & 0.22 & -0.56 \\
\hline 13 & $13-1,72-74$ & -0.08 & -2.84 & -0.49 \\
\hline 14 & $14-1,84-86$ & -0.16 & 0.37 & -0.31 \\
\hline 15 & $15-2,70-72$ & -0.39 & 0.56 & 1.12 \\
\hline 16 & $16-2,80-82$ & -0.20 & 0.39 & -0.65 \\
\hline 17 & $17-1,86-88$ & -0.19 & 0.32 & -0.66 \\
\hline 18 & $19-1,70-72$ & 0.34 & 0.38 & -0.69 \\
\hline 19 & $20-1,70-72$ & -0.35 & 0.47 & -0.55 \\
\hline 20 & $21-1,70-72$ & -0.70 & 0.80 & -0.50 \\
\hline 21 & $22-2,121-123$ & -0.52 & 0.65 & -0.49 \\
\hline 22 & $24-1,93-95$ & 0.53 & 0.42 & -0.07 \\
\hline 23 & $25-1,23-25$ & -0.55 & 0.51 & -0.47 \\
\hline 24 & $26-1,118-120$ & -0.37 & 0.44 & 0.07 \\
\hline 25 & $27-1,118-120$ & 1.02 & -0.18 & -1.12 \\
\hline 26 & $30-1,100-102$ & 0.43 & -0.12 & -0.85 \\
\hline 27 & $33-1,61-63$ & -0.49 & 0.41 & -0.53 \\
\hline 28 & $34-1,32-34$ & 0.93 & -0.42 & -1.10 \\
\hline 29 & $38-1,40-41$ & 0.21 & 0.23 & -0.78 \\
\hline 30 & $43-1,50-51$ & 0.90 & 0.15 & -1.09 \\
\hline 31 & $48-1,64-66$ & 0.14 & -0.08 & -0.66 \\
\hline 32 & $50-1,64-65$ & -0.62 & -0.06 & -0.16 \\
\hline 33 & $55-1,4-5$ & 0.80 & -0.34 & 0.52 \\
\hline 34 & $56-1,35-36$ & 0.18 & 0.27 & -0.71 \\
\hline 35 & $57-1,22-23$ & 0.15 & -0.19 & 0.22 \\
\hline 36 & $58-2,97-98$ & -0.02 & -3.27 & 2.44 \\
\hline 37 & $59-1,65-67$ & 0.03 & 0.45 & 1.96 \\
\hline 38 & $60-1,75-78$ & 5.59 & 2.33 & 2.65 \\
\hline 39 & $60-4,81-82$ & 1.71 & -1.14 & 0.36 \\
\hline 40 & $61-1,27-28$ & -0.48 & 0.27 & 1.97 \\
\hline 41 & $62-1,15-16$ & 0.56 & -0.49 & 0.76 \\
\hline 42 & $63-1,104-105$ & -1.35 & 0.70 & 2.48 \\
\hline 43 & $64-2,82-84$ & -1.09 & 1.00 & 0.24 \\
\hline 44 & $65-1,30-31$ & -0.59 & 0.46 & -0.14 \\
\hline 45 & $66-3,16-18$ & 0.25 & -0.38 & -0.14 \\
\hline 46 & $67-1,25-27$ & -0.49 & -0.22 & -0.04 \\
\hline 47 & $69-3,15-16$ & -0.11 & -0.82 & 0.49 \\
\hline 48 & $70-5,99-100$ & 1.28 & 0.84 & -1.17 \\
\hline 49 & $71-4,41-42$ & -0.58 & -1.27 & 0.23 \\
\hline 50 & $72-2,104-105$ & -0.69 & 0.40 & 0.33 \\
\hline 51 & $73-3,18-19$ & 0.14 & -2.18 & 0.13 \\
\hline 52 & $74-1,69-70$ & 0.41 & -1.03 & -0.50 \\
\hline 53 & $75-1,78-79$ & 0.83 & 0.35 & -1.06 \\
\hline 54 & $77-1,0-1$ & -0.48 & 0.79 & -0.41 \\
\hline 55 & $81-1,26-27$ & -0.48 & 0.96 & 1.86 \\
\hline 56 & $82-1,25-26$ & 0.39 & -0.98 & -0.47 \\
\hline 57 & $83-1,86-87$ & 0.14 & -0.52 & 0.61 \\
\hline 58 & $85-1,100-101$ & -2.35 & 0.99 & 2.55 \\
\hline
\end{tabular}

phates, Figure 2), whereas in the Late Cretaceous, particularly in the early Maastrichtian, rather high rates of phosphorus accumulation resulted from the position of the region in the equatorial zone of high biological productivity. 


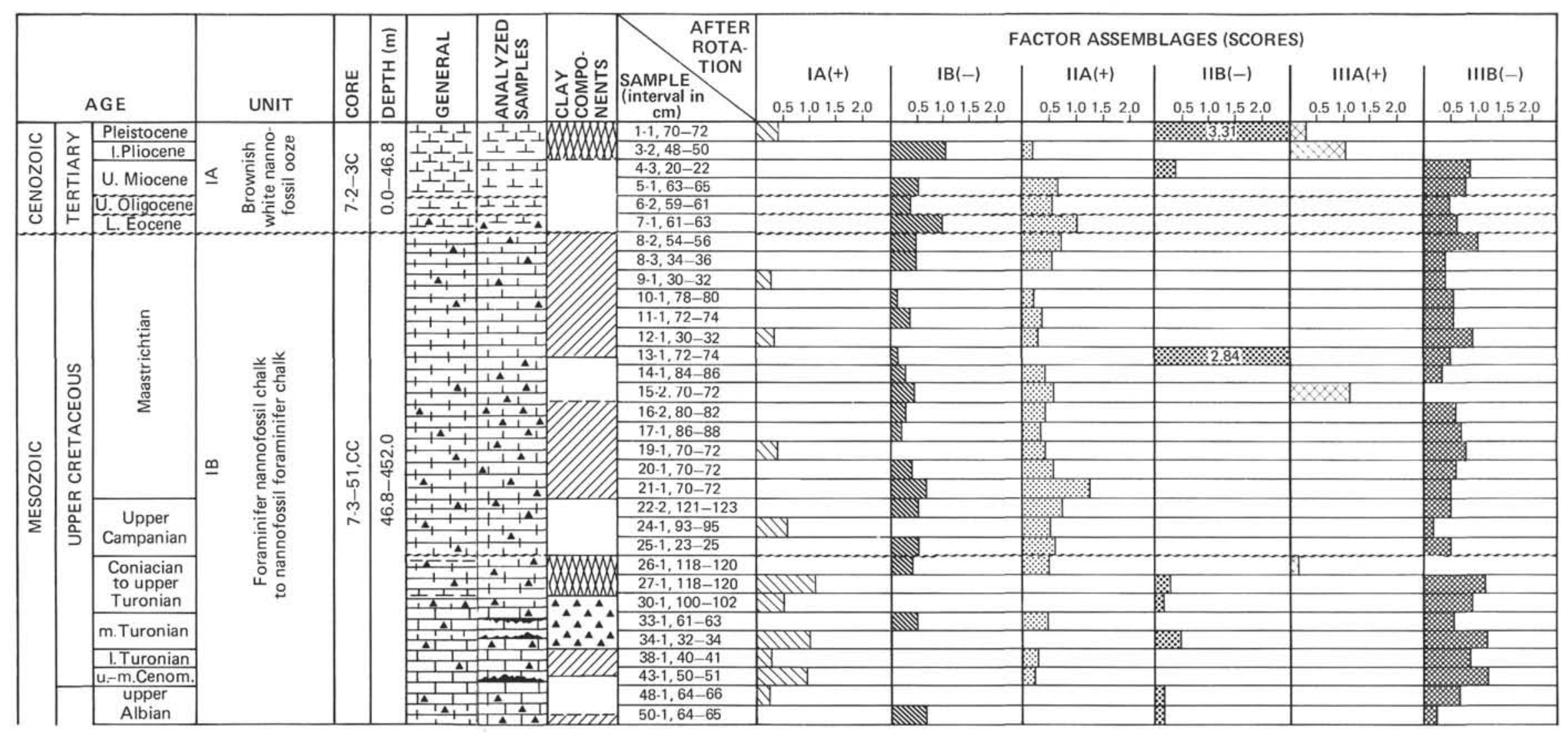




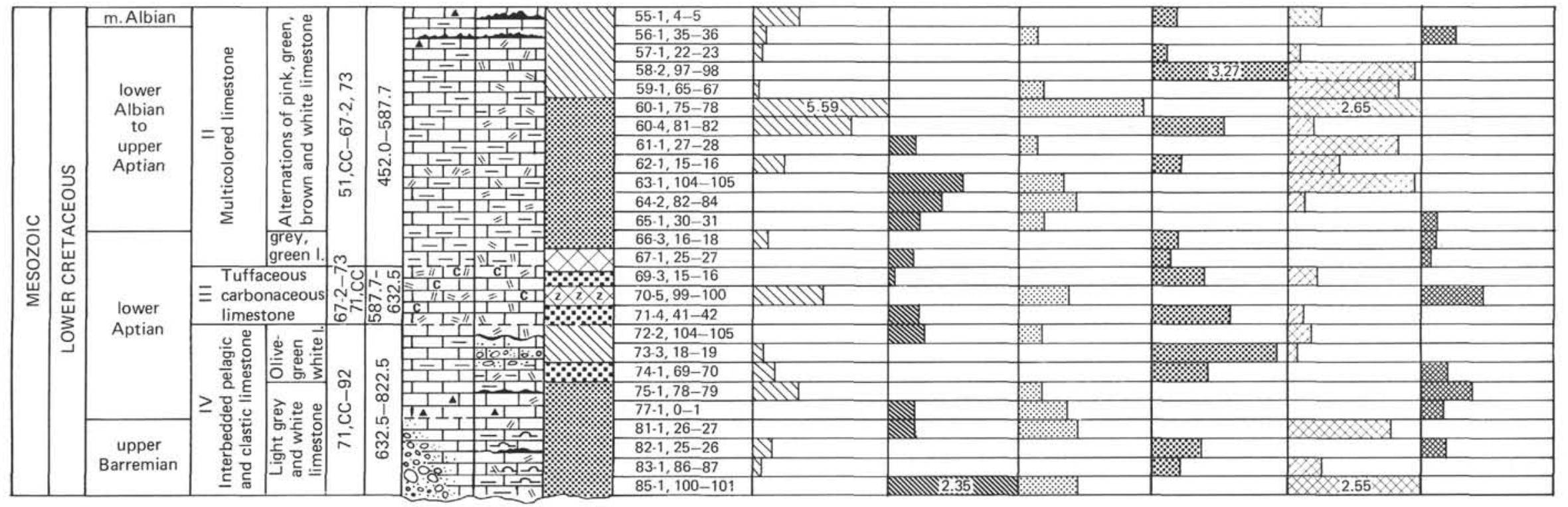

CLAY COMPONENTS

Myxed-layered montmorillonite- illite
phase (M-1) with little admixture

I(DISPERSION $35.02 \%)$

$A(+)$
II (DISPERSION $18.25 \%$ )

$A(+)$
III (DISPERSION 16.24\%)

$A(+)$

Montmorillonite-zeolite assemblage

NIIII Illite with admixture of mixed- layered

wnw

Illite admixed with chlorite

Illite admixed with montmorillonite

2.272 Mixed-layered phase of montmorillonite

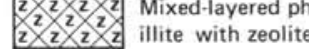

Cristobalie and tridymite

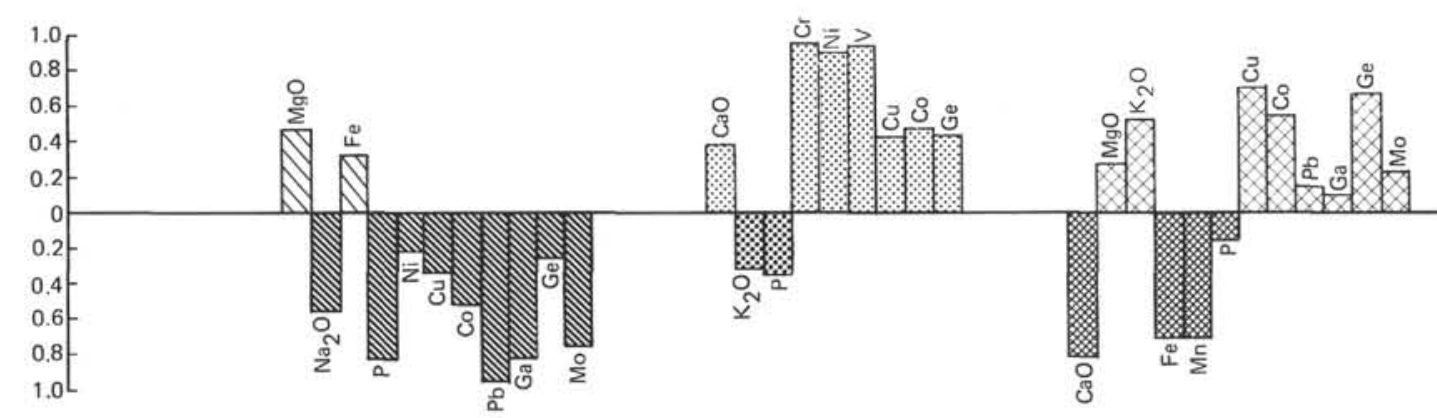

$B(-)$

B(-)

B(-)

Figure 2. Stratigraphic distribution of factor scores for the main paragenetic assemblages of chemical components (chemical analyses recalculated to mineral-free) in the post-Jurassic sequence of the central northwest Pacific, western Mid-Pacific Mountains, DSDP Site 463. See lithologic and clay-component symbols for Figure 1. 
Table 7. Average contents and average rates of accumulation of sediments and the main components for major geochronological subdivisions of the section of post-Jurassic sediments, northwestern Pacific, Mid-Pacific Mountains, DSDP Site 463.

\begin{tabular}{|c|c|c|c|c|c|c|c|c|c|c|c|c|}
\hline \multirow[b]{2}{*}{ Unit } & \multirow[b]{2}{*}{ Lithology } & \multirow[b]{2}{*}{$\begin{array}{l}\text { Sub-bottom } \\
\text { Depth } \\
\text { (m) }\end{array}$} & \multirow[b]{2}{*}{$\begin{array}{l}\text { Thickness } \\
\text { (m) }\end{array}$} & & \multirow[b]{2}{*}{$\begin{array}{c}\text { Sub-bottom } \\
\text { Depth } \\
\text { (m) }\end{array}$} & \multirow[b]{2}{*}{$\begin{array}{l}\text { Thickness } \\
\text { (m) }\end{array}$} & \multicolumn{3}{|c|}{ Physical Parameters } & \multicolumn{2}{|c|}{ Mean Rates of Sedimentation } \\
\hline & & & & Stratigraphy & Core & & & $\begin{array}{l}\text { Density } \\
\left(\mathrm{g} / \mathrm{cm}^{3}\right)\end{array}$ & $\begin{array}{l}\text { Water } \\
\text { Content } \\
(\%)\end{array}$ & $\begin{array}{c}\text { Time } \\
\text { Interval } \\
(\text { m.y.) }\end{array}$ & $\left(\mathrm{m} \cdot 10^{-6} \mathrm{yr}^{-1}\right)$ & (mg $\cdot \mathrm{cm}^{-2} \cdot 10^{-3} \mathrm{yr}^{-1}$ ) \\
\hline \multirow{7}{*}{ 1A } & Nannofossil ooze & $0.0-46.8$ & 46.8 & Pleistocene & & & 4.5 & 1.61 & 37.52 & 1.8 & 2.5 & 310 \\
\hline & 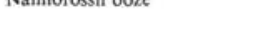 & $0.0=40.8$ & 40.8 & $\begin{array}{l}\text { U. Pliocene } \\
\text { U }\end{array}$ & $1-4: 2-5$ & $4.5-13.0$ & 8.5 & 1.61 & $\begin{array}{l}37.52 \\
37.52\end{array}$ & 1.0 & 8.5 & 1050 \\
\hline & & & & L. Pliocene & $2-6: 3-2-110$ & $13.0-17.6$ & 4.6 & 1.61 & 37.52 & 2.0 & 2.3 & 280 \\
\hline & & & & U. Miocene & $3-2-110: 4-\mathrm{CC}$ & $17.6-34.0$ & 16.4 & 1.61 & 37.52 & 5.3 & 3.1 & 380 \\
\hline & & & & U. Oligocene & $5-1-0: 6-6-20$ & $34.0-43.2$ & 9.2 & 1.61 & 34.85 & 8.0 & 1.2 & 150 \\
\hline & & & & M.-L. Eocene & 6-6-20: $7-2-30$ & $43.2-46.8$ & 3.6 & 1.61 & 32.87 & 4.5 & 0.8 & 100 \\
\hline & & & & L. Maastr. & $7-2-30: 21-5-40$ & $46.8-182.9$ & 136.1 & $\begin{array}{l}1.78 \\
1.86\end{array}$ & 32.10 & 5 & 27.2 & 4185 \\
\hline \multirow[t]{7}{*}{ IB } & Foraminifer-nannofossil chalk & $46.8-452.0$ & 405.2 & U. Campan. & $21-5.40: 26-1 \cdot 30$ & $182.9-214.8$ & 31.9 & $\begin{array}{l}7.86 \\
1.86\end{array}$ & 28.25 & 4.0 & 4.64 & 750 \\
\hline & and nannofossil foraminifer & & & Coniacian to upper Turonian & $26-1-30: 30-\mathrm{CC}$ & $214.8-262.0$ & 47.2 & 1.86 & 27.80 & 4.0 & 6.4 & 980 \\
\hline & & & & U. Turon. & 31-1: $32-\mathrm{CC}$ & $262.0-281.0$ & 19.0 & 1.89 & 24.95 & 2.0 & 9.5 & 1560 \\
\hline & & & & M. Turon. & 32-CC: $34-3-50$ & $281.0-294.0$ & 13.0 & 1.89 & 29.37 & 2.0 & 6.5 & 1040 \\
\hline & & & & $\begin{array}{l}\text { L. Turon. } \\
\text { U.-M. Cenoman. }\end{array}$ & $\begin{array}{l}\text { 34-3-50: 39-CC } \\
40-1: 43-\mathrm{CC}\end{array}$ & $\begin{array}{l}294.0-347.5 \\
34.5\end{array}$ & 53.5 & 1.89 & 28.17 & 2.0 & $\begin{array}{l}26.7 \\
127\end{array}$ & $\begin{array}{l}4310 \\
2090-3-20\end{array}$ \\
\hline & & & & $\begin{array}{l}\text { U.-M. Cenoman. } \\
\text { L. Cenom. }\end{array}$ & $\begin{array}{l}40-1-434-C C \\
44-1: 48-1-40\end{array}$ & $\begin{array}{l}348.75-385.5 \\
385.5-423.9\end{array}$ & $\begin{array}{l}\begin{array}{l}38.0 \\
38.4\end{array}- \\
-\end{array}$ & $\begin{array}{l}1.93 \\
1.93\end{array}$ & $\begin{array}{l}28.17(?) \\
28.17(?)\end{array}$ & $\begin{array}{l}3.0 \\
2.5\end{array}$ & $\begin{array}{l}12.7 \\
15.4\end{array}$ & 2540 \\
\hline & & & & U. Albian & 48-1-40: $51-\mathrm{CC}$ & $423.9-452.0$ & 28.1 & 1.93 & 23.85 & & & \\
\hline \multirow[t]{5}{*}{ II } & Multicolored limestones & $452.0-587.7$ & 135.7 & U. Albian & S1-CC: 52.1 & $452.0-461.5$ & 9.5 & 2.15 & $23.85(?)$ & 4.0 & 9.5 & 1820 \\
\hline & & & & M. Albian & S3-1: $55-1-1.20$ & $461.5-480.7$ & 19.2 & 2.15 & 16.98 & 2.0 & 9.6 & 1900 \\
\hline & & & & $\begin{array}{l}\text { U. Appian-L. AAbian } \\
\text { U. Aptian-L. Albian }\}\end{array}$ & $\begin{array}{l}\text { 55-1-20: 57-CC } \\
\text { 57-CC 59-CC }\end{array}$ & $\begin{array}{l}488.7-487.7 \\
487,7-528.0\end{array}$ & $\begin{array}{r}7.0 \\
40.3\end{array}$ & $\begin{array}{l}2.15 \\
2.15\end{array}$ & $\begin{array}{r}12.80 \\
8.18\end{array}$ & & & \\
\hline & & & & U. Aptian-L. Albian & $60-1: 65-1$ & $528.0-567.5$ & 39.5 & 2.36 & 10.17 & 6.0 & 14.5 & 3260 \\
\hline & & & & L. Aptian ] & 65-2: $66-\mathrm{CC}$ & $567,5-587.7$ & 20.2 & 2.36 & 11.29 & & & \\
\hline III & $\begin{array}{l}\text { Tuffaceous and carbonaceous } \\
\text { limestones }\end{array}$ & $587.7-632.5$ & 44.8 & L. Aptian & 66-CC: 71 & $587.7-632.5$ & 44.8 & 2.18 & 13.81 & & & \\
\hline \multirow{2}{*}{ IV } & $\begin{array}{l}\text { limestones } \\
\text { Interbedded pelagic and }\end{array}$ & $632.5-822.5$ & 190.0 & & & & & & & 3.0 & 44.0 & 9590 \\
\hline & clastic limestone & & & $\begin{array}{l}\text { Apuan } \\
\text { U. Barr. }\end{array}$ & $78-1 ; 92-1$ & $699.0-822.5$ & $\begin{array}{l}\infty 6.3 \\
123.5\end{array}$ & 2,35 & 7.33 & 3.0 & 41.16 & 9370 \\
\hline
\end{tabular}

otes: Determinations of physical parameters of natural wet-bulk samples according to
dry basis (with regard to natural bulk water content), according to shipboard data.

Table 8. Average contents and average rates of accumulation of sediments and the main components for major geochronological subdivisions of the section of post-Jurassic sediments, northwestern Pacific, Mid-Pacific Mountains, DSDP Site 463.

\begin{tabular}{|c|c|c|c|c|c|c|c|c|c|c|c|c|c|c|c|c|}
\hline \multirow[b]{3}{*}{ Stratigraphy } & \multirow[b]{3}{*}{ Core } & \multicolumn{13}{|c|}{ Average Contents (wt. \%) and Average Accumulation Rates of Components (mg $\cdot \mathrm{cm}^{-2} \cdot 10^{-3} \mathrm{yr}^{-}$) } & & \\
\hline & & \multirow{2}{*}{$\begin{array}{l}\text { Sub-bottom } \\
\text { Depth } \\
(\mathrm{m})\end{array}$} & \multicolumn{2}{|c|}{$\mathrm{SiO}_{2}$} & \multicolumn{2}{|c|}{$\mathrm{Al}_{2} \mathrm{O}_{3}$} & \multicolumn{2}{|c|}{$\mathrm{CaCO}_{3}$} & \multicolumn{2}{|c|}{$\mathrm{Fe}$} & \multicolumn{2}{|c|}{$\mathrm{Mn}$} & \multicolumn{2}{|r|}{ P } & \multicolumn{2}{|c|}{$\mathrm{C}_{\text {org }}$} \\
\hline & & & Content & $\begin{array}{c}\text { Accum. } \\
\text { Rate }\end{array}$ & Content & $\begin{array}{c}\text { Accum. } \\
\text { Rate }\end{array}$ & Content & $\begin{array}{c}\text { Accum. } \\
\text { Rate }\end{array}$ & Content & $\begin{array}{c}\text { Accum. } \\
\text { Rate }\end{array}$ & Content & $\begin{array}{l}\text { Accum. } \\
\text { Rate }\end{array}$ & Content & $\begin{array}{l}\text { Accum. } \\
\text { Rate }\end{array}$ & Content & $\begin{array}{c}\text { Accum. } \\
\text { Rate }\end{array}$ \\
\hline Pleistocene & $1-1$ to $1-3$ & 4.5 & 9.19 & 28.5 & 2.93 & 9.1 & 80.06 & 248 & 1.04 & 3.2 & 0.06 & 0.2 & 0.05 & $0.0016 \cdot 10^{2}$ & nil & 0.0 \\
\hline U. Pliocene & $1-4$ to $2-5$ & $4.5-13.0$ & - & - & $-\overline{7}$ & - & - & $\overline{-0}$ & - & - & - & - & - & & - & - \\
\hline L. Pliocene & $2-6$ to $3-2-110$ & $13.0-17.6$ & 2.16 & 6.0 & 0.70 & 2.0 & 93.64 & 262 & 0.48 & 1.3 & 0.04 & 0.1 & 0.05 & $0.0014 \cdot 10^{2}$ & nil & 0.0 \\
\hline U. Miocene & $3-2-110$ to $4, C C$ & $17.6-34.0$ & 2.46 & 9.3 & 1.02 & 3.9 & 89.62 & 340 & 0.39 & 1.5 & 0.05 & 0.19 & 0.07 & $0.0027 \cdot 10^{2}$ & nil & 0.0 \\
\hline U. Oligocene & $5-1-0$ to $6-6-20$ & $34.0-43.2$ & 0.30 & 0.5 & 0.09 & 0.1 & 96.44 & 144 & 0.22 & 0.3 & 0.03 & 0.05 & 0.03 & $0.0005 \cdot 10^{2}$ & nil & 0.0 \\
\hline M.-L. Eocene & $6-6-20$ to $7-2-30$ & $43.2-46.8$ & 0.32 & 0.3 & nil & - & 97.24 & 97 & 0.12 & 0.1 & 0.09 & 0.09 & 0.04 & $0.0004 \cdot 10^{2}$ & nil & 0.0 \\
\hline Maastr. & $7-2-30$ to $21-5-40$ & $46.8-182.9$ & 10.95 & 229.0 & 0.40 & 8.4 & 84.62 & 1770 & 0.31 & 6.2 & 0.02 & 0.4 & 0.02 & $0.0004 \cdot 10^{2}$ & nil & 0.0 \\
\hline U. Campanian & $21-5-40$ to $26-1-30$ & $182.9-214.8$ & 4.15 & 31.1 & 0.12 & 0.9 & 89.65 & 672 & 0.38 & 2.9 & 0.01 & 0.08 & 0.03 & $0.0023 \cdot 10^{2}$ & nil & 0.0 \\
\hline Coniacian to Upper Turonian & $26-1-30$ to $30, \mathrm{CC}$ & $214.8-262.0$ & 0.18 & 1.8 & nil & & 91.02 & 892 & 0.41 & 4.0 & 0.03 & 0.29 & 0.03 & $0.0029 \cdot 10^{2}$ & 0.10 & 0.98 \\
\hline U. Turonian & $31-0$ to $32, \mathrm{CC}$ & $262.0-281.0$ & & & & & & & 0.65 & 6.8 & 0.03 & 0.31 & 0.02 & $0.0021 \cdot 10^{2}$ & nil & 0.0 \\
\hline M. Turonian & $32, \mathrm{CC}$ to $34-3-50$ & $281.0-294.0$ & 6.5 & 67.6 & 0.42 & 4.4 & 87.40 & 909 & 0.38 & 16.3 & 0.04 & 1.72 & 0.03 & $0.0129 \cdot 10^{2}$ & nil & 0.0 \\
\hline L. Turonian & $34-3-50$ to $39, \mathrm{CC}$ & $294.0-347.5$ & 3.02 & 130.2 & 0.43 & 18.5 & 93.14 & 4014 & 0.53 & 11.1 & 0.03 & 0.63 & 0.02 & $0.0042 \cdot 10^{2}$ & nil & 0.0 \\
\hline U.-M. Cenomanian & $40-1$ to $43, C C$ & $347.5-385.5$ & 0.28 & 5.8 & nil & 0.0 & 91.73 & 1917 & - & - & - & - & - & - & - & - \\
\hline L. Cenomanian & $44-1$ to $48-1-40$ & $385.5-423.9$ & - & - & nil & - & - & - & - & - & - & - & - & - & - & - \\
\hline U. Albian & $48-1-40$ to $51, \mathrm{CC}$ & $423.9-452.0$ & - & - & - & - & - & - & - & - & - & - & - & - & - & - \\
\hline U. Albian & $51, \mathrm{CC}$ to $52-1$ & $452.0-461.5$ & 24.73 & 450.1 & 1.03 & 18.7 & 69.71 & 1268 & 0.50 & 9.1 & 0.03 & 0.55 & 0.04 & $0.0073 \cdot 10^{2}$ & nil & 0.0 \\
\hline M. Albian & $53-1$ to $55-1-20$ & $461.5-480.7$ & 27.96 & 531.2 & 0.27 & 5.1 & 64.82 & 1231 & 1.48 & 28.1 & 0.05 & 0.95 & 0.04 & $0.008 \cdot 10^{2}$ & nil & 0.0 \\
\hline U. Aptian-L. Albian & $55-1-20$ to $65-1$ & $480.7-567.5$ & 18.31 & 596.9 & 2.39 & 77.9 & 69.51 & 2266 & 1.09 & 35.5 & 0.02 & 0.65 & 0.03 & 0.010 & nil & 0.0 \\
\hline L. Aptian & $65-2$ to $66, \mathrm{CC}$ & $567-5-587.7$ & 18.10 & 1735.8 & 1.05 & 100.7 & 74.23 & 7119 & 0.68 & 65.2 & 0.05 & 4.8 & 0.02 & 0.019 & nil & 0.0 \\
\hline L. Aptian & $67-1$ to 71 & $587.7-632.5$ & 42.47 & 4072.9 & 1.56 & 149.6 & 39.60 & 3797 & 1.01 & 96.8 & 0.08 & 7.7 & 0.02 & $0.019 \cdot 10^{2}$ & $0.53(1.35)$ & $\begin{array}{r}50.8 \\
129.5\end{array}$ \\
\hline L. Aptian & 71 to $78-1$ & $632.5-699.0$ & 33.37 & 3200.2 & 1.34 & 128.5 & 49.00 & 4699 & 0.68 & 65.2 & 0.06 & 5.8 & 0.03 & $0.029 \cdot 10^{2}$ & nil & 0.0 \\
\hline U. Barremian & $78-1$ to $92-1$ & $699.0-822.5$ & 28.06 & 2629.2 & 1.23 & 115.2 & 66.49 & 6230 & 0.55 & 51.5 & 0.02 & 1.9 & 0.02 & $0.019 \cdot 10^{2}$ & nil & 0.0 \\
\hline
\end{tabular}




\begin{tabular}{|c|c|c|c|c|c|c|c|c|c|}
\hline \multirow[b]{2}{*}{ AGE } & \multirow[b]{2}{*}{$\begin{array}{ccc}\mathrm{SiO}_{2} & \\
10 & 20 \quad 30 & 40\end{array}$} & \multicolumn{5}{|c|}{ COMPONENTS (\%, wt., AVERAGE VALUES) } & \multirow[b]{2}{*}{\begin{tabular}{|r|r}
$\mathrm{MnCO}_{3}$ \\
0.02 & 0.06
\end{tabular}} & \multirow[b]{2}{*}{$\begin{array}{c}\mathrm{FeCO}_{3} \\
0.20 .40 .60 .8\end{array}$} & \multirow[b]{2}{*}{$\begin{array}{c}\mathrm{MgCO}_{3} \\
0.20,40.60 .8\end{array}$} \\
\hline & & $\begin{array}{c}\mathrm{Al}_{2} \mathrm{O}_{3} \\
2{ }_{4}\end{array}$ & ${ }_{20} \mathrm{CaCO}_{3}$ & $\begin{array}{c}\mathrm{Fe} \\
0.51 .01 .52 .0\end{array}$ & \begin{tabular}{|ll} 
& \multicolumn{1}{|c}{$\mathrm{Mn}$} \\
0.02 & 0.06
\end{tabular} & \begin{tabular}{|ll} 
& $P$ \\
0.02 & 0.06
\end{tabular} & & & \\
\hline Pleistocene & & & & 3 & $x$ & & 0.0 & 0.0 & 0.0 \\
\hline L. Pliocene & & & & & & & 0.0 & 0.0 & 0.0 \\
\hline E. Pliocene & & & & & $m$ & & $x^{x} x^{x} x^{x} x^{x} x^{x} x^{x}$ & & 0.0 \\
\hline L. Miocene & & & & & 4 & 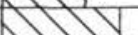 & $\frac{\frac{x}{0} .0}{0.0}$ & & \\
\hline \multicolumn{10}{|l|}{ M. Miocene } \\
\hline \multicolumn{10}{|l|}{ E. Miocene } \\
\hline L. Oligocene & & & & & (8) & D. & 0.0 & 0.0 & 0.0 \\
\hline \multirow{2}{*}{\multicolumn{10}{|c|}{$\begin{array}{l}\text { E. Oligocene } \\
\text { L. Eocene }\end{array}$}} \\
\hline & & & & & & & & & \\
\hline M. Eocene & & & & & & & 0.0 & 0.0 & 0.0 \\
\hline E. Eocene & & & & 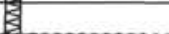 & & & 0.0 & 0.0 & 0.0 \\
\hline \multirow{2}{*}{\multicolumn{10}{|c|}{$\begin{array}{l}\text { L. Paleocene } \\
\text { E. Paleocenen }\end{array}$}} \\
\hline \multicolumn{3}{|l|}{ E. Paleocene } & & & & & & & \\
\hline Maastrichtian & & & & 8 & $\otimes$ & & 0.0 & 0.0 & 0.0 \\
\hline L. Campanian & & & & sest & 1 & & 0.0 & 0.0 & 0.0 \\
\hline \multicolumn{10}{|l|}{ E. Campanian } \\
\hline \multicolumn{10}{|l|}{ L. Santonian } \\
\hline \multicolumn{10}{|l|}{ E. Santonian } \\
\hline L. Coniacian & & & & 8 & 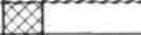 & & $\begin{array}{l}x \times x \\
x \times x \\
x \times x\end{array}$ & & 0.0 \\
\hline E. Coniacian & & & & A & 1 & y & $\mid \begin{array}{l}x \times x \\
x^{x} x \\
x^{x} x\end{array}$ & & 0.0 \\
\hline L. Turonian & & & & 1 & 1 & N & $x \times x y$ & & 0.0 \\
\hline \multicolumn{10}{|l|}{ M. Turonian } \\
\hline E. Turonian & & & & 싯 & $m$ & & 0.0 & 0.0 & 0.0 \\
\hline \multicolumn{10}{|l|}{ L. Cenomanian } \\
\hline \multicolumn{10}{|l|}{ M. Cenomanian } \\
\hline \multicolumn{10}{|l|}{ E. Cenomanian } \\
\hline L. Albian & & & & ses & $2 x$ & $V$ & & & \\
\hline M. Albian & & & & & $x$ & $B$ & $x^{x} x^{x} x^{x} x^{x} x^{x} x^{x}$ & & \\
\hline \multicolumn{10}{|l|}{ E. Albian } \\
\hline \multicolumn{10}{|l|}{ L. Aptian } \\
\hline \multicolumn{10}{|l|}{ E. Aptian (limest.) } \\
\hline \multicolumn{10}{|l|}{ E. Aptian (tuff. l.) } \\
\hline \multicolumn{10}{|l|}{ E. Aptian (clastic I.) } \\
\hline L. Barremian & & & & 悉 & $x$ & $\mathrm{~N}$ & $\mid$ & & 多 \\
\hline
\end{tabular}

Figure 3. Distribution of average concentrations (wt. \%, air-dry) for $\mathrm{SiO}_{2}, \mathrm{Al}_{2} \mathrm{O}_{3}, \mathrm{Fe}, \mathrm{Mn}, \mathrm{P}$, and normative $\mathrm{CaCO}_{3}, \mathrm{MnCO}_{3}, \mathrm{FeCO}_{3}$, and $\mathrm{MgCO}_{3}$ in the post-Jurassic section of the central northwest Pacific, western Mid-Pacific Mountains, DSDP Site 463.

\section{GEOCHEMICAL HISTORY OF SEDIMENTATION}

Vernadsky repeatedly stressed $(1960$, p. 272$)$ that "geochemistry is a history of atoms in the body of our planet" referring to the ideas by M. Faraday and $\mathrm{Ch}$. Schönbein from their work in the 1830 s and 1840 s. This thesis is particularly useful for understanding the geochemical evolution of sedimentation in the world ocean during the Mesozoic and Cenozoic. Numerous works published during the last few years on the evolution of oceanic sedimentation in the Mesozoic and Cenozoic (van Andel et al., 1974, 1975, 1976; Berggren and Hollister, 1977; among others), are mainly devoted to the distribution of carbonate and siliceous components in the sediments and factors controlling their accumulation-change in the depths of the CCD and the lysocline, values of dissolution gradients, relative position of zones with high biological productivity, configuration of paleocurrents, tectonic movements of ocean-bottom structures, etc. These works reveal the main features of sedimentary evolution. However, in combination with the main components, features of distribution of heavy metals and trace elements, and the forms of their occurrence in sediments, this can be interpreted as information which documents the main events of geochemical history of sedimentation.

Analysis of the studied material permits subdivision of the geochemical history of sedimentation in the western Mid-Pacific Mountains into three main stages, with several phases and intervals:

1) Early Cretaceous stage (late Barremian-middle Albian; 118-104 m.y.). The stage concerned is characterized by accumulation of relatively shallow-water carbonate deposits, considerably enriched in $\mathrm{Mn}, \mathrm{Fe}, \mathrm{SiO}_{2}$, $\mathrm{Al}_{2} \mathrm{O}_{3}$, and associated heavy metals, supplied in the form of the basic volcaniclastic material and hydrothermal exhalations (Tables 1-8; Figs. 1-5). Several phases and intervals with distinctly expressed geochemical features are identified within the Early Cretaceous, distinguished by progressive subsidence of the ocean bottom and deepening of the basin.

a) Late Barremian-Early Aptian.

i) Late Barremian. In the interval concerned, the accumulation of deposits represented by alternation of clastic limestones, frequently of turbiditic origin, and fine-grained carbonate sediments took place. The amount and size of the clastic fragments decrease upward in the interval. It should be emphasized that the 


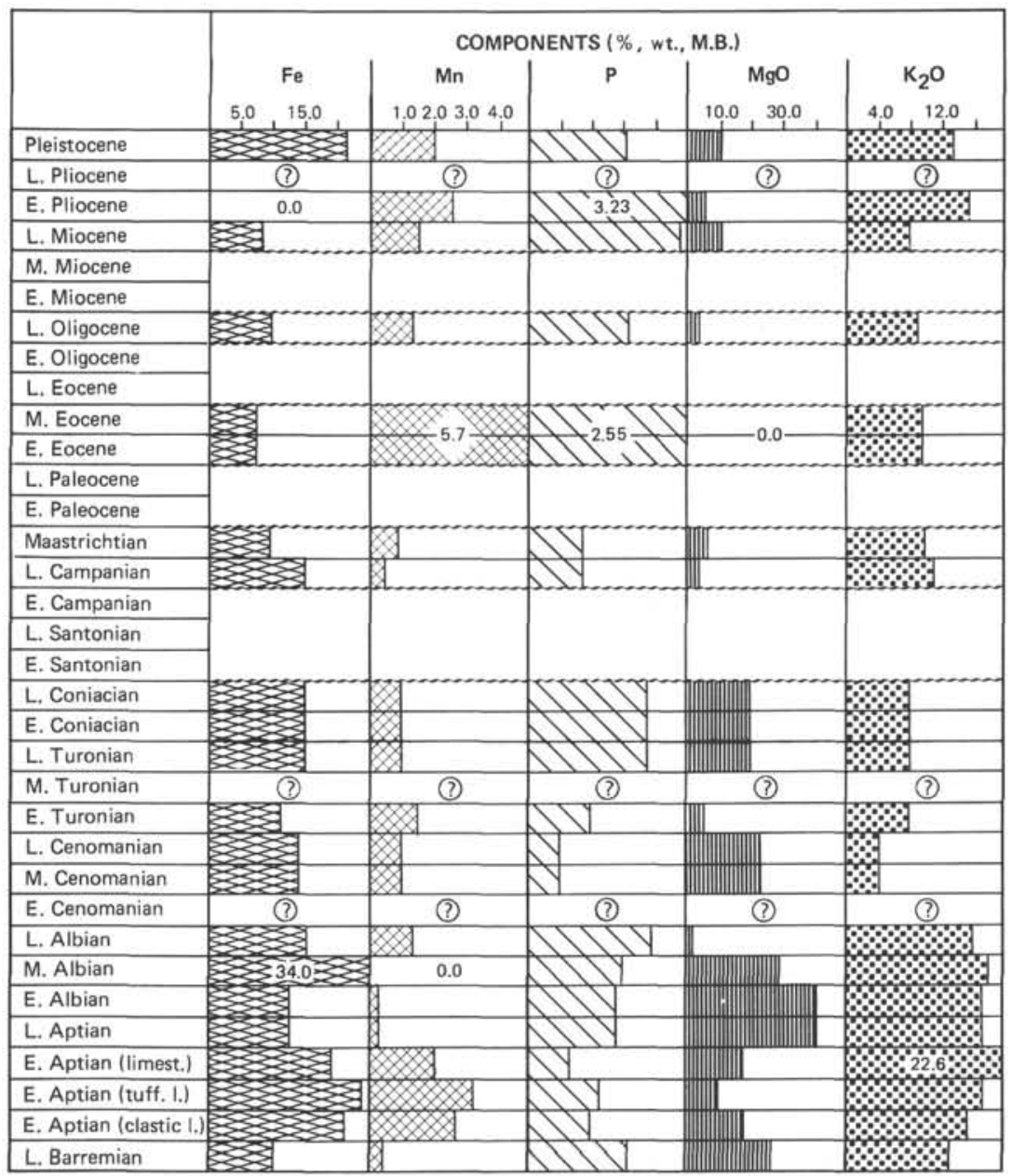

Figure 4. Distribution of average concentration (wt. \%, recalculated to mineral-free) for $\mathrm{Fe}, \mathrm{Mn}, \mathrm{P}, \mathrm{MgO}$, and $\mathrm{K}_{2} \mathrm{O}$ in the post-Jurassic sequence of the central northwest $\mathrm{Pa}$ cific, western Mid-Pacific Mountains, DSDP Site 463.

calcareous fragments are represented by fine-grained limestones, oolite, coarse shells of pelecypods, corals, stromatolites, algae, basalt particles, and rarely quartz. The main mass of clastic and fine-grained limestones is represented by intensively recrystallized nannomicrite, with a variable amounts of radiolarian remains (up to $50 \%$ ), basic-glass particles (up to $20 \%$ ), and clays (illite-smectite) from the alteration of volcaniclastic material.

Upper Jurassic redeposited radiolarians (Site 463 report, this volume) in sediments at the sequence base enables us to estimate approximately the minimum age of destroyed sedimentary rocks.

Worthy of attention is the high accumulation rate of these sediments: $41.16 \mathrm{~mm} \cdot 10^{-3} \mathrm{yr}^{-1}$, or $9370 \mathrm{mg} \cdot \mathrm{cm}^{-2}$ - $\mathrm{yr}^{-1}$ (Tables 7 and 8; Fig. 5). Similar values were assessed for the initial stage in development of protooceanic basins (Tiercelin and Faure, 1978).

Accumulation of these sediments took place in a relatively shallow-water basin, with destruction of coral reefs, bioherms, and islands and pronounced explosive volcanic and hydrothermal activity. These features of formation were reflected in the chemical composition of the deposits (Figs. 1-4). Chemical analyses recalculated to a mineral-free basis (Figs. 2 and 3 ) show that this major part of heavy metals of the sediments is present in the form of basic volcaniclastic material and illite-smectitic products of their alteration [Fig. 2; assemblages IB $(-)$, IIIA (+)]. The occurrence of $\mathrm{Al}_{2} \mathrm{O}_{3}, \mathrm{P}$, and heavy metals enables us to conclude that the high accumulation rates of these components resulted from their abundant contribution to the proto-oceanic basin mainly in a form of basic volcaniclastic material.

ii) Early Aptian (early part). During this period, accumulation of sediments similar in many respects to the late Barremain sediments took place (alternation of clastics and fine-grained carbonates).

The interval concerned is generally characterized by a progressive increase of fine-grained, clastic and calcareous deposits upward in the section. The main mass of sediments is composed of foraminifers and nannofossils, with a considerable amount of radiolarians (up to $30 \%$ ), siliceous sponge spicules, and particles of basic green-olive to brown glass and hyalopelite (up to $20 \%$ ).

These sediments, in their geochemical characteristics, are generally close to early Barremian sediments. However, some increase in deep-water deposits and a relative increase in basic volcaniclastic materials are reflected 


\begin{tabular}{|c|c|c|c|c|c|c|c|c|}
\hline \multirow[b]{2}{*}{ AGE } & \multicolumn{2}{|c|}{ SEDIMENTS } & \multicolumn{6}{|c|}{ COMPONENTS (MG Cm $\mathrm{Cm}^{-2} 10^{-3} \mathrm{yr}^{-1}$ ) } \\
\hline & $\begin{array}{c}\text { Мм См-2 } \\
10^{-3} \mathrm{yr}^{-1} \\
10 \quad 20 \quad 30 \quad 40\end{array}$ & $\begin{array}{c}\text { MG } \mathrm{CM}^{-2} \\
10^{-3} \mathrm{yr}^{-1} \\
1000 \quad 3000\end{array}$ & $\begin{array}{r}\mathrm{CaCO}_{3} \\
2000 \quad 6000\end{array}$ & $\begin{array}{cc}\mathrm{SiO}_{2} \\
500 & 1500\end{array}$ & $\begin{array}{c}\mathrm{Al}_{2} \mathrm{O}_{3} \\
2040 \quad 6080\end{array}$ & $\begin{array}{c}\mathbf{F e} \\
10 \quad 20 \quad 30 \quad 40\end{array}$ & 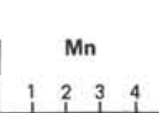 & $\begin{array}{c}P \\
0.20 .40 .60 .8\end{array}$ \\
\hline Pleistocene & $: 1$ & . & & & & & & \\
\hline L. Pliocene & $\because$ & Fi & (7) & (7) & (2) & (7) & (2) & (7) \\
\hline E. Pliocene & i & & & & & & & \\
\hline L. Miocene & 23 & & & & & & & \\
\hline M. Miocene & & & & & & & & \\
\hline E. Miocene & & & & & & & & \\
\hline L. Oligocene & 5 & & & & & & & \\
\hline E. Oligocene & & & & & & & & \\
\hline L. Eocene & & & & & & & & \\
\hline M. Eocene & 3 & & & & & & & \\
\hline E. Eocene & 1 & & & 0.3 & & & & \\
\hline L. Paleocene & & & & & & & & \\
\hline E. Paleocene & & & & & & & & \\
\hline Maastrichtian & $\because$ & & & A & 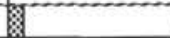 & 8 & gु & \\
\hline L. Campanian & . & 9 & & 31.1 & 0.9 & 臬 & 0.08 & \\
\hline E. Campanian & & & & & & & & \\
\hline L. Santonian & & & & & & & & \\
\hline E. Santonian & & & & & & & & \\
\hline L. Coniacian & $1=$ & 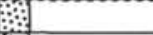 & & 1.8 & $\mathrm{Ni}$ & 目 & 8 & \\
\hline E. Coniacian & :1: & 6 & & 1.8 & $\mathrm{Ni}$ & 蒠 & & \\
\hline L. Turonian & $\because$ & 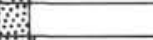 & & 1.8 & $\mathrm{Ni}$ & 8 & & \\
\hline M. Turonian & $\therefore$ & H & & 67.6 & 4.4 & 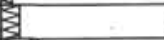 & & \\
\hline E. Turonian & $\because \because \because \because 1$ & W & & 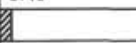 & 双 & 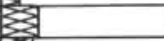 & $m$ & 1.29 \\
\hline L. Cenomanian & $\because$ & i & & 5.8 & $\mathrm{Ni}$ & 至 & & \\
\hline M. Cenomanian & $\because$ & $\%$ & & 5.8 & $\mathrm{Ni}$ & . & d & \\
\hline E. Cenomanian & $\because 1$ & 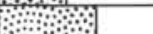 & & & & & & \\
\hline L. Albian & $\therefore$ & ; & & & 双 & ళ & 8 & \\
\hline M. Albian & $\therefore$ & 4 & & & 5.1 & se्s & x & \\
\hline E. Albian & $\because$ & Has & & & & sडs & & \\
\hline L. Aptian & $\therefore$ & in & & & & ssis] & & \\
\hline E. Aptian (limest.) & $\because \because$ & o & & & 1000.7 & 65.2 & $x m 2 x$ & $\sqrt{1.9}$ \\
\hline E. Aptian (tuff. I.) & $\because$ & $49590 \div$ & & 4072 & 149.66 & 896.8 & $7.7 \times$ & 1.9 \\
\hline E. Aptian (clastic I.) & 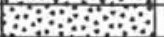 & W & & 3200 & 8128.5 & 65.2 & 5.8 & 2.97 \\
\hline L. Barremian & i & 5370 & & 2629.2 & (11.5.2. & 85.5 & $x$ & 1.90 \\
\hline
\end{tabular}

Figure 5. Distribution of average rates of sedimentation and component accumulation for $\mathrm{CaCO}_{3}, \mathrm{SiO}_{2}, \mathrm{Al}_{2} \mathrm{O}_{3}, \mathrm{Fe}, \mathrm{Mn}$, and $\mathrm{P}$ in the post-Jurassic sequence of the central northwest Pacific, western Mid-Pacific Mountains, DSDP Site 463.

in the relatively higher concentrations of $\mathrm{Mn}, \mathrm{Fe}$, and heavy metals (Figs. 3, 4) and corresponding increases of accumulation rates of these components (Fig. 5). For example, average rates of accumulation of $\mathrm{Mn}(6.3$ $\left.\mathrm{mg} \cdot \mathrm{cm}^{-2} \cdot 10^{-3} \mathrm{yr}^{-1}\right)$ and $\mathrm{Fe}\left(81.0 \mathrm{mg} \cdot \mathrm{cm}^{-2} \cdot 10^{-3} \mathrm{yr}^{-1}\right)$ suggest that some part of the heavy metals was contributed by hydrothermal sources (Boström, 1973; Bender et al., 1971).

b) Early Aptian (middle part). This interval is known for accumulation of carbonate sediments enriched in basic tuffaceous material and organic sapropelic matter, concentrations of organic carbon making up as much as $5 \%$ in some interlayers. The considerable amounts of volcaniclastic materials and organic matter result in the gray color of the sediments. The main mass $(60-70 \%)$ of these sediments is represented by bioclastic micrite (in rocks with intensively recrystallized calcite), with an essential admixture of fine hyalopelitic material transformed into smectite-illitic components (up to $50 \%$ ), zeolites, and dispersed carbonaceous organic matter with fragments of organic tissues (up to 2-5\%). Intensive, post-sedimentary recrystallization of carbonate micrite was accompanied by partial dissolution of vol- canogenic material and formation of rosette-shaped segregations of sederite-ankerite-ferromagnesite. Dispersed segregations of pyrite are observed in the main mass. The carbonate sediments of this time, as a whole, are characterized by a relatively higher (compared to the earlier deposits; up to 30-40\%) amount of basaltic volcaniclastic material, including fragments of greenbrown glass, and enrichment in sapropelic material.

The deposits concerned have relatively high concentrations of $\mathrm{Mn}, \mathrm{Fe}$, and associated heavy metals (Figs. 3 and 4). The data of factor analysis, confirmed by mineralogical methods, suggest that these metals are present together with organic matter in smectite-illite products of altered basaltic volcaniclastic material in the form of organometallic compounds [assemblages IA $(+)$ and IIIB (-); Fig. 1], as well as in the form of a smectite-illitic phase proper [assemblage IIA (+); Fig. 1].

It is of interest that the accumulation rates of $\mathrm{SiO}_{2}$, $\mathrm{Al}_{2} \mathrm{O}_{3}, \mathrm{Fe}, \mathrm{Mn}$, and associated heavy metals during this period was characterized by maximum values for the Mesozoic and Cenozoic (Tables 7 and 8; Fig. 5). It is particularly true for $\mathrm{Fe}\left(96.8 \mathrm{mg} \cdot \mathrm{cm}^{-2} \cdot 10^{-3} \mathrm{yr}^{-1}\right)$ and $\mathrm{Mn}\left(7.7 \mathrm{mg} \cdot \mathrm{cm}^{-2} \cdot 10^{-3} \mathrm{yr}^{-1}\right)$, their values suggesting at 
least partial contribution of hydrothermal material to the sedimentation basin. Accumulation rates of $\mathrm{Fe}$ and Mn for sediments of the East Pacific Rise respectively make up 63 to 110 and 24 to $35 \mathrm{mg} \cdot \mathrm{cm}^{-2} \cdot 10^{-1} \mathrm{yr}^{-1}$ (Boström, 1973; Bender et al., 1971), whereas for the sediments of the open ocean they do not exceed 2.4 to 9.0 for Fe and 0.4 to 4.0 for Mn (McArthur and Elderfield, 1977). However, in interpretation of the values of component accumulation rates, it should be kept in mind that during the early Aptian the region of the western Mid-Pacific Mountains was generally characterized by the highest rates of sedimentation for the Mesozoic and Cenozoic: $9590 \mathrm{mg} \cdot \mathrm{cm}^{-2} \cdot 10^{-3} \mathrm{yr}^{-1}$ (Fig. 5; Tables 7 and 8).

The available information of geochemistry, mineralogy, and lithology of these sediments gives evidence that their accumulation took place in a relatively shallow stagnant basin or depression with restricted water exchange and pronounced oxygen deficiency. In such a basin, rapid accumulation of nannoplankton carbonate oozes took place, frequently with fragments of mollusk shells, enriched in sapropelic organic matter, plant detritus and volcaniclastic basaltic material, hyalosilt, and hyalopelite. Products of terrestrial island volcanism are predominant, whereas materials of hydrothermal exhalations reworked in the process of post-sedimentary transformations into sulfide, carbonate compounds are present in lesser amounts. Traces of mud-eaters and bioturbation in sediments suggest the presence of benthic activity in some intervals. However, high amounts accumulating organic matter in the basin and the limited, stagnant hydrological regime of the bottom waters provided the development of pronounced reducing environments, confirmed by the observed sulfides, Fe-carbonates, and the component assemblages determined by factor analysis. It should be stressed that similar, synchronous sediments were recovered on the Shatsky Rise, in the Nauru Basin, and in many regions of the Atlantic and Indian Oceans. These data allow us to outline a global Early Cretaceous phase in oceanic sedimentary evolution. However, the lateral distribution of such tuffaceous sediments with high content of organic carbon was not continuous. The stagnant-water sediments in the Pacific Ocean and other basins are spatially replaced by synchronous deposits with faunal, lithologic, and geochemical features indicating normal oxygen conditions (Schlanger and Jenkyns, 1976).

c) Early Aptian (later part)-Late Albian. During the phase, biogenic carbonate sediments with variable amounts of radiolarian remains accumulated. The deposits are represented by cyclic multicolored alternations of differently colored varieties. Within this part of the section, a definitely expressed tendency of upward color change of cycles is observed: (1) dark-gray, olive, and greenish varieties (early Aptian; Cores 66 and 67); (2) alternation of green, brown, pink, and white sediments (early Aptian-early Albian; Cores 57-65); (3) alternation of white, pale-green, and light-greenish-gray varieties (early Albian-late Albian; Cores 52-55).
The pronounced trend in this change of color is governed by the composition of the sediments, their redox condition, and the oxygen regime of the bottom waters.

The presence of relatively coarse-grained material (remains of foraminifers, radiolarians, bimorphic fragments, and fragments of limestone) at the base of many cyclic series and basal erosional boundaries may be regarded as evidence for a change from active hydrodynamic environments to relatively quiet ones-and in many cases this indicates turbidites.

The main mass of the deposits concerned is represented by recrystallized nannofossil micrite (up to 60$70 \%$ ) and remains of foraminifers (up to $20 \%$ ) in gray varieties, with notable amounts of dispersed organic matter (up to $1.0-1.5 \%$ ); whereas in red varieties there are $\mathrm{Fe}$-hydroxides. An admixture of dark-green and brown basaltic-glass chips and intensively altered volcaniclastic material in sediments not older than late Aptian makes up $10 \%$. Fragments of pelecypod shells, calcareous sponges, and dinoflagellates are also found. Remains of radiolarians transformed into opal-CT make up 5 to $25 \%$. Recrystallization of nannofossil micritic matter of the main mass of sediments was accompanied by dissolution of silicate, hydroxide, and volcanogenic admixtures, and formation of epigenetic segregations of $\mathrm{Fe}-\mathrm{Mn}-\mathrm{Mg}$-carbonates (Fig. 3).

The sediments of the time concerned have relatively high concentrations of $\mathrm{Al}_{2} \mathrm{O}_{3}, \mathrm{Fe}, \mathrm{Mn}$, and associated heavy metals (Figs. 1-5). The data of factor analysis and examination of clay components (Figs. 1 and 2) show that a considerable part of the $\mathrm{Fe}, \mathrm{Mn}, \mathrm{Ni}, \mathrm{Co}, \mathrm{Cu}, \mathrm{V}$, $\mathrm{Cr}$, etc., is present in the form of basaltic volcaniclastic material, transformed into $\mathrm{Fe}-\mathrm{Mg}$ illite-smectitic phases [assemblage IA (+), and particularly IIB (-); Fig. 1]. Excluding the diluting influence of carbonate (Fig. 2), the significance of Fe-hydroxides developed in the volcaniclastic material [IIA (+)] and illite-smectite products [IIIA $(+)$ ] is more obvious. These conclusions are in good agreement with the highest concentrations of $\mathrm{K}_{2} \mathrm{O}$ recalculated to a mineral-free basis (Fig. 4); this is indicative of intensive illitization of the basic volcaniclastic material of this period.

Changes of sedimentation rates during the period concerned shows their distinct decrease towards the beginning of the late Albian (Tables 7 and 8; Fig. 5). The decrease in the $\mathrm{Al}_{2} \mathrm{O}_{3}, \mathrm{Fe}$, and $\mathrm{Mn}$ accumulation rates is particularly pronounced. It resulted not only from decrease of sedimentation rates, but also from a reduction of these component amounts in the sediments toward the later intervals of the phase; this in turn is related to a weakening of volcanism. However, this tendency cannot be applied to phosphorus, which had relatively high rates of accumulation and did not change significantly during this time (Fig. 5; Tables 7 and 8). The given data show that $\mathrm{P}$ has a dual geochemical nature: it was supplied to the basin of sedimentation from volcanic sources [assemblages IB (-), IIB (-); Fig. 2], and in the form of biogenic products, intensively trans- 
formed in the course of post-sedimentary alteration. Moreover, the data on distribution of average $\mathrm{P}$ content recalculated to air-dry weight and mineral-free basis (Figs. 3 and 4) show a pronounced increase from the early Aptian to the beginning of the late Albian.

Features of lithologic, mineral and chemical composition of the sediments, and their structure allow us to draw definite conclusions on conditions of sedimentation: the sediments accumulated in environments of a relatively shallow sea, considerably above the CCD of that time, abundant in leveled, considerably peneplaned, guyots, reefs, and bioherm shoals. During the initial intervals (up to the beginning of the early Albian), considerable amounts of basaltic volcaniclastic materials were supplied to the basin, while pelagic foraminifer-nannofossil oozes were deposited in hydrodynamically active environments (some parts of the sedimentary unit have distinct characteristics of turbidites). After late Aptian-late Albian times, a progressive deepening of the basin took place, in association with a sharp reduction of volcanic activity. Accumulation of sediments took place in normally oxygenated environments. These conclusions are in good agreement with the $\mathrm{Fe}$-oxide forms and the corresponding color of the sediment (predominance of pale pink and greenish colors).

Thus, the period from the later intervals of the early Aptian to the beginning of the late Albian can be regarded as the final stage of the Early Cretaceous-the initial stage in development of this part of the Pacific Ocean. The proto-oceanic basin during this time underwent progressive deepening and became a part of a more-opened ocean.

2) Late Cretaceous stage: Late Albian-Maastrichtian. (104.0-65.0 m.y.). Within this stage, there was accumulation of foraminifer-nannofossil micrite and nannofossil-foraminifer oozes, relatively homogenous, with considerable amounts of siliceous remains transformed into opal-CT, quartz, and chalcedonic segregations. The sediments are characterized by relatively constant contents of $\mathrm{CaCO}_{3}, \mathrm{Al}_{2} \mathrm{O}_{3}, \mathrm{Fe}, \mathrm{Mn}$, and heavy metals (Figs. 1-5; Tables 1-8).

The Late Cretaceous can be subdivided into two phases, with a lacuna between.

a) Late Albian-Coniacian to Upper Turonian. Lithologic data on these sediments are elsewhere in this volume. Despite a somewhat incomplete geochemical description (little information from the Coniacian to upper Turonian), the contents of main components and their accumulation rates within this phase did not change considerably. Relatively higher concentrations of $\mathrm{Al}_{2} \mathrm{O}_{3}$ and $\mathrm{SiO}_{2}$ are noted only in lower Albian sediments; this is because of the dying-out of volcanic activity, which was actively manifested in the Early Cretaceous. $\mathrm{Mn}$ and $\mathrm{Fe}$ accumulation rates do not exceed the values (Tables 7 and 8; Fig. 5) peculiar to pelagic zones of the world ocean (McArthur and Elderfield, 1977; Bender, 1970; Boström et al., 1973). $\mathrm{CaCO}_{3}$ shows a considerable increase in accumulation rate from the late
Albian-early Cenomanian to the Turonian (1618.1 to 2850.1-2569.6 mg $\left.\cdot \mathrm{cm}^{-1} \cdot 10^{-3} \mathrm{yr}^{-1}\right)$. Such a change in accumulation rates of carbonates possibly can be connected with the position of Site 463 in the southern marginal part of the relatively wide (at that time) equatorial zone of high biological productivity with general movement of the Pacific Plate northward (Berggren and Hollister, 1977). A pronounced impoverishment of the sediments of that period in heavy metals, present predominantly in the form of illitic and smectitic components (Figs. 1 and 2), is of interest.

i) Hiatus in sedimentation: Upper Campanian to Coniacian. This hiatus in the western Mid-Pacific Mountains is distinctly expressed; to the northeast, on Hess Rise, its erosional effect was governed by specific features in development of block structures.

The geochronological range of the hiatus is larger in the western parts of the region than in its eastern and northeast parts. This fact allows us to suggest the association of hiatus development with the activation of the Late Cretaceous analog of the circumequatorial currents and their northwest branches (Luyendyk et al., 1972).

b) Upper Campanian to Maastrichtian. The phase concerned can be subdivided into two intervals with different sedimentation environments and chemical composition of sediments.

i) Upper Campanian. The lithologic-mineral composition and geochemistry of the sediments concerned are rather stable. The low rates of accumulation of $\mathrm{CaCO}_{3}, \mathrm{Al}_{2} \mathrm{O}_{3}, \mathrm{Fe}$, and $\mathrm{Mn}$ are similar to those in the Coniacian to upper Turonian and are possibly due to an increase of the lysocline level.

ii) Maastrichtian. The lithological composition of the sediments concerned is typical of the Late Cretaceous. Noteworthy is a certain increase in $\mathrm{SiO}_{2}$ and $\mathrm{Mn}$ concentrations, possibly due to high biological productivity during this interval, along with the features of residual accumulation at the base of the most considerably hiatus. This conclusion is confirmed by analysis of distribution of components (Fig. 1): the sediments of the uppermost Early Maastrichtian (basal boundary of the hiatus) are enriched in illite-smectitic components. Rather high accumulation rates of $\mathrm{CaCO}_{3}, \mathrm{SiO}_{2}$, $\mathrm{P}, \mathrm{Fe}, \mathrm{Mn}$, and associated heavy metals (Fig. 5; Tables 7 and 8 ) are of particular interest. The problem of the appearance of intervals with high rates of accumulation in the Mesozoic and Cenozoic section has been discussed widely during the last few years (Winterer, 1973; Berger, 1973, van Andel, 1974; van Andel et al., 1975, 1976; Lancelot and Larson, 1975); these papers provide data on sedimentation, paleomagnetism, absolute age of basement rocks, and paleotectonic reconstructions. Analysis of the available data shows that in the Maastrichtian Site 463 was in the equatorial zone of high biological productivity. Accumulation of sediments took place in pelagic environments considerably shallower than the lysocline of that time. Thus, the northward movement of the Pacific Plate was registered in the sedi- 
ments during the passage across the equatorial zone of high biological productivity; this is generally in agreement with the results of our study.

3) Cenozoic stage (65.0-0.0 m.y.). The Cenozoic stage considerably differs from the previous ones. It shows sharp changes in the geochemical history of sedimentation, which after the Oligocene was characterized by features similar to the Recent. It is subdivided into several phases and intervals.

a) Hiatus in sedimentation: Maastrichtian-Early Eocene. The hiatus between the Mesozoic and Cenozoic has at least regional significance for the Pacific Ocean. During this phase, the Mid-Pacific Mountains crossed the equatorial zone of high biological productivity, with the general northward movement of the Pacific Plate, and entered the northern oligotrophic region, with more aggressive behavior of waters toward carbonate and silica, and high rates of erosion (van Andel et al., 1975, 1976).

b) Early Eocene. During the phase concerned, foraminifer-nannofossil oozes accumulated practically without aluminosilicate admixtures, but with relatively high concentrations of disseminated Mn and P (Fig. 4). Extremely low rates of sedimentation (Fig. 5; Tables 7 and 8) show that early Eocene sediments are relics left by succeeding erosion (middle Eocene-early Oligocene). The increased concentrations of $\mathrm{Mn}$ and $\mathrm{P}$ in these sediments can be attributed to their relict nature. The data on oxygen isotopes and reconstruction of paleotemperatures (Frakes and Kemp, 1972, 1973) and paleogeography (Berggren and Hollister, 1977) show that in the Pacific Ocean up to $60^{\circ} \mathrm{N}$ a warm (subtropical) humid climate was predominant during the Eocene, which drastically changed in the Oligocene.

c) Hiatus in sedimentation: Middle Eocene-Late Oligocene. The hiatus concerned is at least of regional extent for the Pacific Ocean, with drastic changes of climate at the Eocene/Oligocene boundary, accompanied by a radical reconstruction of the system of oceanic currents (Frakes and Kemp, 1972, 1973). Invasion of cold Antarctic bottom waters of high density and salinity, aggressive toward carbonate and silicates, into the Central Pacific caused intensive erosion and dissolution of sediments (Shackleton and Kennett, 1975a,b). The events concerned finally resulted in the appearance of a wide strait between Australia and Antarctica, and are related to the formation of Antarctic sea ice (Berggren and Hollister, 1977).

d) Late Oligocene. During the phase concerned, foraminifer-nannoplankton oozes with moderate concentrations of $\mathrm{Fe}, \mathrm{Mn}$, and heavy metals accumulated (Figs. 1-4). The rather low rates of accumulation of the sediments and components enable us to conclude that during that time the CCD and lysocline were at a relatively shallow depth, owing to invasion of Antarctic bottom waters with high aggressiveness into the West Pacific (Shackleton and Kennett, 1975 a,b). Unlike the western Mid-Pacific Mountains, the more-eastern regions of the central Pacific in the late Oligocene had the highest rates of carbonate accumulation for the Cenozoic (van Andel et al., 1975, 1976). e) Hiatus in sedimentation: Early-Middle Miocene. The hiatus concerned is of regional scale for the Pacific Ocean. The CCD of that time was rather shallow. During that phase, the recent structure of deep-sea circulation was formed. The factors associated with the main formation of Antarctic glaciation play a key role in sedimentation within the Pacific (Shackleton and Kennett, 1975 a,b; van Andel et al., 1975, 1976).

f) Late Miocene-Pliocene. The sedimentation history during this phase for the central Pacific was rich in numerous changing events. However, the western Mid-Pacific Mountains had a relatively stable sedimentary environment: it was a time of accumulation of foraminifer-nannofossil sediments with relatively low concentrations of $\mathrm{Al}_{2} \mathrm{O}_{3}, \mathrm{Fe}, \mathrm{Mn}$, and heavy metals (Figs. 1-5). Relatively high concentrations of $\mathrm{Fe}, \mathrm{Mn}$, and heavy metals, and a corresponding increase in the rate of their accumulation, are observed in the Pleistocene, owing to activation of island acidic and basaltic volcanism.

\section{CONCLUSIONS}

Study of distribution of the main components and heavy metals and modes of their occurrence in association with the data on mineralogy of post-Jurassic sediments in the western Mid-Pacific Mountains allows us to outline three main stages in the geochemical history of sedimentation: (1) Early Cretaceous, (2) Late Cretaceous, (3) and Cenozoic.

1) Early Cretaceous (late Barremian-late Albian). This stage is distinguished by accumulation of relatively shallow-water carbonate sediments, with considerable amounts of basaltic volcaniclastic material and relatively high concentrations of heavy metals, mainly in the form of volcaniclastic components altered to illitesmectitic and to a lesser extent products of hydrothermal exhalations. Volcanic activity was at a maximum in the middle part of the early Aptian, with accumulation of tuffaceous carbonate oozes rich in organic matter in the environments of a stagnant basin. The high accumulation rates of the main components and heavy metals are close to the values observed for initial proto-oceanic stages in development of rift basins.

2) Late Cretaceous (late Albian-Maastrichtian). This stage had transitional conditions of sedimentation and geochemical parameters, with considerable reduction in concentrations of heavy metals and rates of their accumulation. High rates of $\mathrm{CaCO}_{3}, \mathrm{Al}_{2} \mathrm{O}_{3}, \mathrm{Fe}, \mathrm{Mn}$, and $\mathrm{P}$ accumulation in the early Maastrichtian was the most important feature of the stage. At that time, the western Mid-Pacific Mountains were in the equatorial zone of high biological productivity, with the general northward movement of the Pacific Plate.

3) Cenozoic (Paleocene-Holocene). In this stage are several hiatuses (late Maastrichtian-early Eocene, middle Eocene-late Oligocene; late Oligocene-late Miocene), and a rather stable accumulation regime of foraminifer-nannoplankton oozes. In many cases, the basal beds are enriched in products of dissolution: clays, Mnhydroxides, and phosphates. 
The studied section shows a distinctly outlined geochemical and sedimentary evolution from the Early Cretaceous relatively shallow-water carbonate deposits with considerable amounts of volcanogenic components to the Pleistocene pelagic oozes.

\section{ACKNOWLEDGMENTS}

The authors express their gratitude to their colleagues at the Geological Institute of the U.S.S.R. Academy of Sciences: P. K. Ryabushkin, D. A. Kazimirov, N. I. Kartoshkina, and N. Yu. Vlasova for efficient assistance in processing analytical data by computer, recalculation of analyses, and technical help; D. Ya. Choporov for accurate control of the analytical data; V. A. Drits, B. A. Sakhorov, and T. G. Eleseeva for X-ray structural analysis of samples; V. I. Koporulin for the provided materials and helpful discussions; V. S. Zelinsky, N. K. Mirskaya, and K. A. Shcheponnikova for assistance in graphic presentation of the materials; I. G. Sheremet, G. N. Surovtseva, and G. V. Kozlovskaya for translation of papers into English.

The authors greatly appreciate the reviewing of the papers and helpful comments by N. G. Brodskaya and V. I. Vinogradov, Geological Institute of the U.S.S.R. Academy of Sciences.

\section{REFERENCES}

Bender, M. L., Broecker, W., Gornitz, V., et al., 1971. Geochemistry of three cores from the East Pacific Rise. Earth Planet. Sci. Lett., $12: 425-433$.

Bender, M. L., Ku, T.-L., and Broecker, W. S., 1970. Accumulation rates of manganese in pelagic sediments and nodules. Earth Planet. Sci. Lett., 8:143-148.

Berger, W., 1973. Cenozoic sedimentation in the Eastern Tropical Pacific. Geol. Soc. Am. Bull., 84:1941-1954.

Berggren, W. A., 1973. The Pliocene time scale: calibration of planktonic foraminiferal and Cretaceous nannoplankton zones. Nature, 243:391-397.

Berggren, W. A., and Hollister, C. D., 1977. Plate tectonics paleocirculation-commotion in the ocean. In Bonnin, J., and Dietz, R. S. (Eds.), Present State of Plate Tectonics: Tectonophys., 38:1148.

Bezrukov, P. L., and Romankevich, E. A., 1970. Rate of sedimentation in Pacific Ocean. In Bezrukov, P. L. (Ed.), Pacific Ocean. Sedimentation in Pacific Ocean (Vol. 2): Moscow (Nauka), 288-300.

Boström, K., 1973. The origin and fate of ferromanganoan active ridge sediments. Stock. Contrib. Geol., 27:149-243.

Boström, K., Kraemer, T., and Gartner, S., 1973. Provenance and accumulation rates of opaline silica, $\mathrm{Al}, \mathrm{Ti}, \mathrm{Fe}, \mathrm{Mn}, \mathrm{Cu}, \mathrm{Ni}$, and $\mathrm{Co}$ in Pacific pelagic sediments. Chem. Geol., 11:123-148.

Davis, J. C., 1973. Statistics and Data Analysis in Geology: New York (Wiley).

Fischer, A. G., Heezen, B. C., et al., 1971. Site 44. In Fischer, A. G., Heezen, B. C., et al., Init. Repts. DSDP, 6: Washington (U.S. Govt. Printing Office), 17-39.

Frakes, L. A., and Kemp, E. M., 1972. Influence and continental positions on early Tertiary climates. Nature, 240:97-100.

1973. Paleocene continental positions and evolution of climate. In Tarling, D. H., and Runcorn, S. K. (Eds.), Implications of Continental Drift to the Earth Sciences (Vol. 1): London (Academic Press), 539-559.

Geological Society of London, 1964. Phanerozoic time scale. Geol. Soc. London Quat. J., 120:260-262.

Hamilton, E. L., 1956. Sunken islands of the Mid-Pacific Mountains. Geol. Soc. Am. Mem., 64.

Hardenbol, J., and Berggren, W. A., 1978. A new Paleogene numerical time scale. Am. Assoc. Petrol. Geol. Stud. Geol., 6:213-234.

Harman, H. H., 1967. Modern Factor Analysis: Chicago (Univ. of Chicago Press).

Heezen, B. C., Hoskins, R. H., Mac Gregor, I. D., et al., 1973. Diachronous deposits: a kinematic interpretation of the post-Jurassic sedimentary sequence on the Pacific Plate. Nature, 241:25-32.
Lancelot, Y., 1978. Relations entre evolution sedimentaire et tectonique de la Plaque Pacifique depuis le Cretace inferieur. Mem. Soc. Geol. France, 57:40.

Lancelot, Y., and Larson, R. L., 1975. Sedimentary and tectonic evolution of the north-western Pacific. In Larson, R. L., Moberly, R., et al., Init. Repts. DSDP, 32: Washington (U.S. Govt. Printing Office), 925-939.

Larson, R. L., and Hilde, T. W. C., 1975. A reversal time scale of magnetic reversals for the Early Cretaceous and Late Jurassic. $J$. Geophys. Res., 80:2586-2594.

Larson, R. L., Moberly, R., et al., 1975. Site 313: Mid-Pacific Mountains. In Larson, R. L., Moberly, R., et al., Init. Repts. DSDP, 32: Washington (U.S. Govt. Printing Office), 313-390.

Lisitzin, A. P., 1974. Sedimentation in Oceans: Moscow (Nauka). , 1978. Processes of Oceanic Sedimentation: Lithology and Geochemistry: Moscow (Nauka).

Luyendyk, B. P., Forsyth, D., and Phillips, J. D., 1972. Experimental approach to the paleocirculation of the oceanic surface waters. Geol. Soc. Am. Bull., 83:2649-2664.

Lyle, M., 1976. Estimation of hydrothermal manganese input to the oceans. Geology, 4:733-736.

McArthur, J. M., and Elderfield, H., 1977. Metal accumulation rates in sediments from Mid-Indian Ocean Ridge and Marie Celeste Fracture Zone. Nature, 266:437-439.

Riley, J. P., and Chester, R., 1971. Introduction to Marine Chemistry: London (Academic Press).

Schlanger, S. O., and Jenkyns, H. C., 1976. Cretaceous oceanic anoxic events: causes and consequences. Geol. Mijnb., 55:179-184.

Shackleton, N. J., and Kennett, J. P., 1975a. Paleotemperature history of the Cenozoic and the initiation of Antarctic glaciation: oxygen and carbon isotope analyses in DSDP Sites 277, 279 and 281. In Kennett, J. P., Houtz, R. E., et al., Init. Repts. DSDP, 29: Washington (U.S. Govt. Printing Office), 743-755.

1975b. Late Cenozoic oxygen and carbon isotopic changes at DSDP Site 284: implications for glacial history of the Northern Hemisphere and Antarctic. In Kennett, J. P., Houtz, R. E., et al., Init. Repts. DSDP, 29: Washington (U.S. Govt. Printing Office), 801-807.

Tiercelin, J. J., Faure, H., 1978. Rates of sedimentation and vertical subsidence in neorifts and paleorifts. Tectonics and Geophysics of Continental Rifts (Vol. 2): Moscow (Dordrechtyea), 41-47.

van Andel, T. H., 1974. Cenozoic migration of the Pacific Plate, northward shift of the axis of deposition, and paleobathymetry of the Central Equatorial Pacific. Geology, 2:507-510.

1975. Mesozoic/Cenozoic calcite compensation depth and the global distribution of calcareous sediments. Earth Planet. Sci. Lett., 26:187-194.

van Andel, Tj. H., Heath, G. R., and Moore, T. C., 1975. Cenozoic history and paleoceanography of the central equatorial Pacific Ocean. Geol. Soc. Am. Mem., 143.

1976. Cenozoic history of the Central Equatorial Pacific: A synthesis based on Deep Sea Drilling Project data. Geophysics of the Pacific Ocean Basin and Its Margin: Washington (Am. Geophys. Union), pp. 201-295.

van Andel, Tj. H., and Moore, T. C., 1974. Cenozoic calcium carbonate distribution and calcite compensation depth in the Central Equatorial Pacific Ocean. Geology, 2:87-92.

Van Eysinga, F. W. B., 1975. Geological Time Table (3rd Ed.): Amsterdam (Elsevier).

Van Hinte, J. E., 1976. A Cretaceous time scale. Bull. Am. Soc. Petrol. Geol., 60:498-516.

Varentsov, I. M., 1978. The geochemistry of heavy metals in Upper Cenozoic sediments near the crest of the Mid-Atlantic Ridge, latitude $23^{\circ} \mathrm{N}$, drilled on DSDP Leg 45 . In Melson, W. G., Rabinowitz, P. D., et al., Init. Repts. DSDP, 45: Washington (U.S. Govt. Printing Office), 349-377.

Varentsov, I. M., and Blazhchishin, A. I., 1976. Ferromanganese nodules. Geology of Baltic Sea: Vilnius (Mokslas), pp. 307-348.

Vernadsky, V. I., 1960. Oceanography and geochemistry. In Vernadsky, V. I., Selected Works (Vol. 5): Moscow (U.S.S.R. Acad. Sci.), 422 . 
Winterer, E., 1973. Sedimentary facies and plate tectonics of Equatorial Pacific. Bull. Am. Assoc. Petrol. Geol., 57:265-282.

1976. Anomalies in the tectonic evolution of the Pacific. Trans. Am. Geophys. Union, 19:269-278.

Winterer, E. L., Ewing, J. I., et al., 1973. Site 171. In Winterer, E. L., Ewing, J. I., et al., Init. Repts. DSDP, 17: Washington (U.S. Govt. Printing Office), 283-334.
Zolotarev, B. P., Choporov, D. Y., 1978. Petrochemistry of basalts D/V Glomar Challenger, Leg 45, Holes 395, 395A and 396. In Melson, W. G., Rabiniwitz, P. D., et al., Init. Repts. DSDP, 45: Washington (U.S. Govt. Printing Office), 479-492. 